\title{
Book Three: Society
}

\section{The past and present Manvantaras}

\section{Maitreya:}

Master, you've given me an excellent and detailed description of the earth, the oceans and the rest, as well as the nature of the sun, the stars and other luminaries. 1

Similarly, you've explained the creation of the gods and sages, and the origin of the four communities and the realm of animals. 2

You've also described in detail the feats of Dhruva and Prahlāda. Now I wish to hear about each Manvantara in order. 3

I'd like to hear you speak of each age's overlord, my guru, with mighty Indra at their head. 4

\section{Parāśara:}

I'll now give you a full and orderly account of the past and future Manvantaras. 5

The initial Manu was Svāyaṃbhuva, then came Svārociṣa, Uttama, Tāmasa, Raivata and Cākṣuṣa. 6

These six Manus have already passed. The current one is Vaivasvata, the Sun's own son, and his Manvantara is the seventh. 7

I've already spoken of the Manvantara of Svāyambhuva at the beginning of the age, and I've told you all about the gods and sages of that period. 8

Now I'll list the overlords, the deities, the seers and their progeny, who lived in the Manvantara of the Manu Svārocișa. 9

During that period, the deities were the Pārāvatas and Satusitas, and mighty Vipaścit was the king of gods, Maitreya. 10 
Ūrja, Stambha, Prāṇa, Dattoli, Ṛsabha, Niścara and Arvarīvant were the seven sages. 11

Caitra, Kimpurușa and others were the sons of Svārocișa. I've described the second Manvantara. Now listen to the one that followed. 12

In the third Manvantara, brahmin, the Manu was named Uttama and the regal deity Suśānti was the king of gods, Maitreya. 13

There were five hosts of deities, the Sudhāmans, Satyas, Sivas, Pratardanas and Vaśavartins, each of which comprised twelve gods. 14

The seven sons of Vasiștha were the seven sages, and Aja, Paraśu, Divya and the others were the sons of Manu Uttama. 15

During the Manvantara of Tāmasa, the deities were Surūpas, Haris, Satyas and Sudhis. Each host had twenty-seven gods. 16

Śibi, also known as Śatakratu or 'Hundred Sacrifices', was their king. Now hear from me the names of the seven sages at that time: 17

Jyotirdhāman, Pṛthu, Kāvya, Caitra, Agni, Vanaka and Pīvara were the sages then. 18

The mighty kings named Nara, Khyāti, Śāntahaya, Jānujañgha and others were the sons of Tàmasa. 19

In the fifth Manvantara, the Manu was known as Raivata by name, and Vibhu was the king of gods, Maitreya. Now listen to the names of the deities of that period: 20

The Amitābhas, Bhūtarayas, Vaikuṇthas and Sumedhases. Each host had fourteen gods. 21

Hiraṇyaroman, Vedaśrī, Ūrdhvabāhu, Vedabāhu, Sudhāman, Parjanya and Mahāmuni were the seven sages during the Manvantara of Raivata, brahmin. 22

The valiant kings Balabandhu, Susambhāvya and Satyaka, among others, were his sons, best of sages. 23

The four Manus Svārocișa, Uttama, Tāmasa and Raivata are thought to be Priyavrata's offspring. 24

Having propitiated Viṣnu with his austerities, the sage-king Priyavrata was granted these Manvantara overlords as his descendants. 25 
In the sixth Manvantara, the Manu was known as Cākṣuṣa, and Manojava was the king of gods. Now hear about the deities: 26

The Āpyas, Prasūtas, Bhavyas, the divine Pṛthugas and the resolute Lekhas were the five hosts, each of which comprised eight deities. 27

Sumedhas, Virajas, Havișmant, Uttama, Madhu, Atināman and Suhiṣnu were the seven sages. 28

The sons of the Manu Cākșuṣa-mighty Ūru and Pūru, with Śatadyumna as the foremost-were the kings. 29

The son of Vivasvat, brahmin, that brilliant god presiding over funerary rites, is the wise Manu who oversees the present Manvantara, the seventh. 30

The Ādityas, Vasus, Rudras and others are the deities of this period, great sage, and Indra, conqueror of cities, is the lord of thirteen gods, Maitreya. 31

Vasișṭha, Kāśyapa, Atri, Jamadagni, Gautama, Viśvāmitra and Bharadvāja are the seven sages of this period. 32

Ikṣvāku, Nṛga, Dhṛșța, Śaryāti, famed Narișyanta, Nābhāga, Dișța, 33

Karūṣa and Pṛsadhra, rich and famous-these are the nine good sons of Manu Vaivasvata. 34

The unequalled energy of Viṣnu, abounding in vitality, infuses all creation and presides over every Manvantara in the form of a deity. 35

A portion of that energy appeared as Yajña during the period of Svāyambhuva. This divine being arose from Svāyambhuva's mind and was born to his daughter $\bar{A}$ kūtī in the first Manvantara. 36

Later, that same deity was born to Tuṣitā as Ajita during the period of Svārocișa, along with the other Tuṣita gods. 37

In the period of Uttama, Tuṣita was born again to Satyā as Satya, together with the peerless Satya deities. 38

And when the period of Tămasa began, he was born again to Harī as Hari, along with the Hari gods. 39

During the period of Raivata, the most excellent deity Hari was born as Saṃbhūta, mind-begotten son of Sambhūtī, along with the Rājasa deities. 40 In the period of Cākṣuṣa, the highest divine spirit was born as Vaikuṇțha to Vikuṇṭhā, together with the Vaikunțha gods. 41 
In the present Vaivasvata Manvantara, brahmin, Viṣnu was born as Vāmana, the divine dwarf, the son of Kaśyapa and Aditi. 42

That great being conquered the threefold worlds in just three strides and entrusted them to Indra, vanquisher of cities, having freed them from all obstacles. 43

Such are the seven forms of Viṣnu, brahmin, arising in each of the seven Manvantaras for the preservation of all creatures. 44

Because the whole world is infused (vistam) with the energy of that great being, he is called Viṣnu, from the root vis', meaning 'enter'. 45

All the gods, the Manus, the seven sages, the Manus' sons, and whoever is Indra, lord of thirteen deities, are all just forms of Viṣnu's might. 46

So ends Chapter One in Book Three of the glorious Viṣnu Purāna.

\section{The future Manvantaras}

\section{Maitreya:}

You've described these seven Manvantaras, brahmin sage, please tell me now about the periods yet to come. 1

Parāśara:

Viśvakarman's daughter Samijñā was married to the Sun, and their offspring were the Manu Vaivasvata, Yama and Yamī, sage. 2

Unable to endure her husband's energy, Samijñā engaged Chāyā to serve him, and she herself retired to the forest to undertake austerities. 3

Thinking Chāyā to be Saṃjñā, the Sun had three more children with her: sluggish Saturn, another Manu named Sāvarṇi, as well as Tapatī. 4

One day, Chāyā, enraged with Yama, cursed him. Only then did Yama and the Sun realise that she wasn't Samijñā. 5

When Chāyā admitted to the Sun that Saṃjñā was in the forest, he perceived through his yogic power that she was practising austerities in the form of a mare. 6

Appearing as a stallion, the Sun mounted Samijñā and sired the heavenly twins the Aśvins, as well as Revanta. 7 
The lordly Sun then led Saṃjñā to his own abode, where Viśvakarman pared back his energy. 8

Turning the Sun upon his lathe, the heavenly craftsman reduced his brilliance by just one-eighth, without impairing his eternal light. 9

The blazing energy of the Sun shaved off by Viśvakarman fell back to earth, best of sages. 10

There, the heavenly artisan Tvașṭr used that energy to fashion Viṣnu's discus, Śiva's trident and a palanquin for wealth-giving Kubera. 11

Viśvakarman then used the rest to make Kārttikeya's lance and all the other deities' weapons. 12

Chāyā's second son was also called a Manu and, because he had the same complexion (savarna) as his elder brother, he was called Sāvarṇi. 13

His Manvantara, the Sāvarṇi period, will be the eighth. Listen, blessed sage, while I describe it for you. 14

Sāvarṇi will be the following Manu, Maitreya, and the Sutapas, Amitābhas and Mukhyas will be the gods. 15

Each host will include twenty deities. Now I'll name the seven sages, best of seers: 16

Dīptimant, Gālava, Rāma, Kṛpa, Drauṇi and my son Vyāsa, with Ṛśyaśṛnga as the seventh. 17

By the grace of Viṣnu, Bali, blameless son of Virocana, whose realm is the underworld of Pātāla, will be the king of gods. 18

The kings Virajas, Arvarīvant, Nirmoha and others will be Manu Sāvarṇi's sons. 19

The ninth Manu will be Dakṣasāvarṇi, Maitreya. 20

The Pāras, Marīcigarbhas and Sudharmans will be the threefold hosts of gods then, each with a dozen deities. 21

Their king will be mighty Adbhuta, brahmin. 22

Savana, Dyutimant, Bhavya, Vasu, Medhātithi and Jyotiṣmant, with Satya as the seventh-these will be the seven great sages. 23

Dhṛtaketu, Dīptiketu, Pañcahasta, Nirāmaya, Pṛthuśravas and others will be Dakṣasāvarṇi's sons. 24 
The tenth Manu will be Brahmasāvarṇi, sage. The gods will be Sudhāmans, Viruddhas and Śatasamkhyas. 25

Mighty Śānti by name will be their king. Now hear about the seven sages of that period: 26

Haviṣmant, Sukṛti, Satya, Apāmmmūrti, Nābhāga, Apratimaujas and Satyaketu. 27

The ten sons of Brahmasāvarnii-Sukșetra, Uttamaujas, Bhūriṣeṇa and the rest-will protect the earth. 28

The eleventh Manu will be Dharmasāvarnika. 29

The Vihamgamas, Kāmagamas and Nirmānarucis will be the principal hosts of deities then, each comprising thirty gods, with Vṛ̦a as their king. 30

Niścara, Agnitejas, Vapuṣmant, Viṣnu, Āruṇi, Haviṣmant and Anagha will be the seven sages. 31

The kings Sarvaga, Sarvadharman, Devānīka and others will be that Manu's sons. 32

The twelfth Manu will be Sāvarṇi, son of Rudra, with Ṛtudhāman as king of gods. Now hear about the deities from me. 33

The Haritas, divine Lohitas, Sumanases, Sukarmans and Supāras will be the hosts of gods, each with fifteen deities, brahmin. 34

Tapasvin, Sutapas, Tapomūrti, Taporati, Tapodhṛti, with Dyuti as another and Tapodhana as the seventh will be the sages. 35

The kings Devavant, Upadeva, Devaśreștha and others will be that Manu's mighty sons. 36

The thirteenth Manu will be known as Raucya, sage. 37

The Sutrāmans, Sukarmans and Sudharmans will be the various hosts of gods, each with thirty-three deities. 38

Mighty Divaspati will be their king. 39

The seven sages will be Nirmoha, Tattvadarśin, Niṣprakampa, Nirutsuka, Dhritimant and Avyaya, with Sutapas as the seventh. 40

The kings will be Citrasena, Vicitra and others. 41

Bhautya will be the fourteenth Manu, Maitreya. Śuci will be the king of gods and there'll be five heavenly hosts. Listen to their names: 42 
The Cākṣuṣas, Pavitras, Kanișțhas, Bhrājiras and Vācāvṛddhas will be the deities. Now hear from me the seven sages: 43

Agnibāhu, Śuci, Śukra, Māgadha, Agrīdhra and Yukta, with Jita as the other. Listen to the Manu's sons: 45

The kings Ūru, Gambhīra, Budhna and others will be the sons of Manu. Those whom I've named will protect the earth, you tiger of a sage. 45

\section{The cycle of ages}

At the end of every cycle of four ages, the Vedas disappear, but seven sages descend from heaven to the world to propound them once again. 46

In each Krta age, a Manu arises to promulgate smrti, the sacred texts recalled by men, brahmin. The deities enjoy the sacrifices during each Manvantara. 47

The Manu's sons and their descendants also rule the world for the duration of that period. 48

A Manu, seven sages, the deities, the Manu's sons who rule the earth and one king of gods preside over every period. 49

When fourteen Manvantaras have passed, an aeon or kalpa of one thousand cycles of four ages is said to be complete. 50

Then comes a night of the same duration, best of sages, during which Viṣnu, who also takes the form of Brahmā, reposes on the serpent Śeșa in the middle of the ocean. 51

After consuming all three worlds, the lord, creator and universal Janārdana, rests amid his own illusory power, brahmin. 52

Following which, the eternal lord awakes, and, taking on the quality of energy, creates the world again at the onset of each new aeon as before. 53

Viṣnu's stainless aspect-which manifests as Manus, sovereigns, seven sages, deities and their kings-maintains the universe, best of brahmins. 54

Now you'll hear how Viṣnu, in the character of the maintainer of the world, undertakes its preservation during every age, Maitreya. 55

In the Kṛta, Viṣnu, at the heart of all creation, delighting in the welfare of the world, takes the form of Kapila and other sages, and teaches highest knowledge. 56 
In the Tretā, in the form of a universal monarch, the lord protects the threefold worlds while destroying wicked beings. 57

In the form of Veda-vyāsa, having split the single Veda into four, the lord arranges these in lesser branches by the hundreds. 58

Once he's arranged the Vedas in the Dvāpara, Lord Hari takes the form of Kalki at the end of the Kali yuga, setting sinners on the path of virtue. 59

In this way, the infinite being creates, protects and, in the end, destroys the world. There's nothing more beside him. 60

I've described to you the past, the present and the future of creation, brahmin, and mighty Viṣnu's actual nature in this world and elsewhere. 61 I've also told you all about the Manvantaras and those who oversee them. What else would you like to hear? 62

So ends Chapter Two in Book Three of the glorious Viṣnu Purāna.

\section{The Vyāsas arrange the Vedas; The syllable $\mathrm{Om}$}

\section{Maitreya:}

I've learned from you how this world is Viṣnu, is in Viṣnu, is from Viṣnu and how there's nothing else beside him. 1

But I'd like to hear how the Vedas are arranged by that great being in the form of a Veda-vyāsa, or 'arranger of the Vedas', in each successive age. 2

Tell me of the varied forms of Vyāsa that appear in every aeon, sage and master, and how the Vedic branches are divided. 3

\section{Parāśara:}

As the Veda-tree is divided into branches by the thousand, Maitreya, it's impossible to describe them one by one, so listen to this summary. 4

In each Dvāpara age, Viṣnu takes the form of Vyāsa, sage, and divides the single Veda into several parts to benefit the world. 5

Seeing humankind lacks courage, strength and energy, he divides the Veda for the good of every being. 6

The form that Viṣnu takes, that enemy of Madhu, when he divides the Veda, is known as 'Veda-vyāsa'. 7 
Now you'll learn about the varied Vyāsas who appear in this Manvantara, sage, and how the division into branches is undertaken. 8

The Vedas have been divided on twenty-eight occasions by great sages during each successive Dvāpara age in this Vaivasvata Manvantara. 9

Twenty-eight Veda-vyāsas, who arranged the Vedas into four in each Dvāpara age, best of sages, have already gone by. 10

In the first Dvāpara, the Vedas were arranged by the self-existent deity Brahmā. In the second, the Veda-vyāsa was the patriarch Manu. 11

In the third, the arranger was Uśanas, and in the fourth Bṛhaspati. Savitr was the arranger in the fifth, and in the sixth was Mrrtyu, Lord of Death. 12

In the seventh it was Indra, and Vasisțha in the eighth, Sārasvata in the ninth and Tridhāman in the tenth. 13

In the eleventh it was Trivṛsan, and Bhāradvāja followed him. In the thirteenth it was Antarikṣa, and Varṇin in the fourteenth, 14

Trayyāruna in the fifteenth, in the sixteenth Dhanamjaya, Kṛtamjaya in the seventeenth and Rnjaya in the eighteenth. 15

The next Vyāsa was Bharadvāja, and after him came Gautama. After Gautama the Vyāsa was Uttama, also known as Haryātman. 16

After Haryātman was Vena or Vājaśravas, then Soma Suṣmāyaṇa or Tṛnabindu. 17

Then came Ṛkṣa, scion of Bhṛgu, also known as Vālmīki. After him was my father, Śakti, sage, and I was the Vyāsa after him. 18

Jātukarṇa followed me, then Kṛ̣na Dvaipāyana. These are the twenty-eight Veda-vyāsas of ancient times. 19

They split the single Veda into four in each Dvāpara age. 20

In the next Dvāpara period, Drona’s son Drauni will be the Vyāsa after my son, the sage Kṛ̣ṇa Dvaipāyana, has passed. 21

\section{The syllable Om and the Absolute}

$O m$ is defined as the Absolute (brabman) in the form of one eternal syllable. It's so called on account of its greatness (brhatvāt) and its capacity to strengthen (brmbanatvāt). 22 
I bow to the Absolute in the form of the everlasting syllable, $O m$, invoked as 'earth, sky and heaven' (bbūr, bhuvas, svah) in the Rg, Yajur, Säma and Atharva Vedas. 23

I bow to the Absolute, known as the cause of creation and destruction of the world, the deepest secret of mabat, the principle of Greatness. 24

Unfathomable, unbound and undecaying, it's the source of illusion in the world. With brilliance and efficacy, it's the cause by which the purpose of the highest spirit is accomplished. 25

The Absolute is the crown for those who know the Sāmkhya teachings, and the goal for those who pacify and regulate themselves. It's unmanifest, undying efficacy. 26

It's also called the essence, the origin of the Self, the heart of all reality. It's indivisible, pure, imperishable and manifold. 27

I bow again and again to that eternal, highest Absolute, a form of Vāsudeva, who is himself a form of the highest spirit. 28

This Absolute is the threefold lord, yet also one. That undivided being is thought to be divided among all creation by those who regard him as divisible. 29

This universal being, composed of the $R g$, Säma and Yajur Vedas, is their essence. He is indeed the heart of all embodied beings. 30

Consisting of the Vedas, he is divided, but he made these texts and splits them into many. The eternal lord is author of their branches, and takes the form of knowledge of them all. 31

So ends Chapter Three in Book Three of the glorious Viṣnu Purāna.

\section{The origin of the four Vedas}

\section{Parāśara:}

The ancient four-limbed Veda had a hundred thousand verses, and all ten kinds of sacrifice, like a wish-fulfilling cow, are derived from it. 1

In this, the twenty-eighth Dvāpara age, my holy scion Vyāsa arranged that single four-limbed text. 2 
Just as wise Veda-vyāsa arranged it, so was it divided by all the former Vyāsas and by me as well. 3

You should know that the division into branches that he undertook, best of brahmins, is likewise done in every fourfold era. 4

Understand that Vyāsa, Kṛ̣na-Dvaipāyana, is Lord Nārāyaṇa himself, Maitreya. Who else on earth could compose the Mahäbhärata? 5

Listen now, Maitreya, while I explain how my great son arranged the Vedas during this Dvāpara age. 6

Urged by Brahmā, he began to organise the texts, and first accepted four disciples, all well-steeped in Vedic lore. 7

That great sage adopted Paila as disciple for the $R g$, and Vaiśampāyana for the Yajur Veda. 8

For the Sāma, Veda-vyāsa took on Jaimini. Sumantu, who understood the Atharva Veda, became a student of that prudent sage. 9

Vyāsa accepted Romaharṣaṇa, a wise disciple, as narrator for the histories and purānas. 10

The Yajur Veda was a single text, but he divided it in four, and, in doing so, he brought about the fourfold cāturhotra sacrifice. 11

The sage assigned the yajus prayers to the director of the sacrifice, the adbvaryu; the $r c$ verses to the sacrificing priest or hotr; the samman hymns to the cantor or udgatr; ; and the atharva incantations to the brahmin. 12

Vyāsa compiled the rc verses as the Rg Veda, yajus prayers as the Yajur Veda and the säman hymns as the Säma Veda. 13

With the atharva incantations, that master created all the rituals for the kings and for the office of the brahmins, as per usage. 14

He split in four that single spreading Veda-tree and so began a Veda forest. 15

\section{The branches of the $\boldsymbol{R g} \mathrm{Veda}$}

First, Paila split the $R g$ in two, and gave one part to Indrapramati and one to Bāṣkala. 16

Wise Bāṣkala split his part in four, and gave each one to his disciples, Baudhya and the others. 17 
Baudhya, Agnimāṭhara, Yājñavalkya and Parāśara, sage, adopted these subsections of that branch. ${ }^{1} 18$

Indrapramati taught one collection to his son, great Māṇdukeya, Maitreya. 19 This was then passed down in turn from his disciples and their disciples to their sons and their disciples. 20

Vedamitra, also known as Śăkalya, studied that collection. He divided it in five and gave each part to his disciples. 21

Now hear their names from me: Mudgala, Gālava, Vātsya and Śālīya, with the great sage Siśira as the fifth, Maitreya. 22

Śākapunni split that same collection differently by dividing it in three and adding an appendix as the fourth division, best of sages. 23

Krauñca, Vaitālaki and Balāka, that great sage, were his disciples, and Nirukta, master of the Vedas and their supplements, was the fourth. 24

This is how the later branches grew from all these subbranches, best of brahmins. Bāṣkala made three other compilations, brahmin. Kālāyani was his disciple, as was Gārgya, with Java as the third. 25

It is they who spread abroad these sets of Vedic verses. 26

So ends Chapter Four in Book Three of the glorious Viṣnu Purāna.

\section{The branches of the Yajur Veda}

\section{Parāśara:}

Vyāsa's wise disciple Vaiśampāyana split the tree-like Yajur Veda into twenty-seven. ${ }^{2} 1$

He then conferred each branch upon his disciples, who accepted them in turn. 2

His disciple Yājñavalkya, Brahmarāta's son, understood the highest virtues and was always dedicated to the service of his master, brahmin. 3

1 Is this the same Parāśara who narrates the Viṣnu Purāna?

2 The verse breaks in this chapter are very messy and I have not followed them strictly. 
'One who fails to join our gathering on Mount Meru for seven nights will be guilty of brahminicide. ${ }^{3} 4$

Such was the first agreement of the gathered sages, brahmin, but Vaiśampāyana was the only one to break it. 5

He later tripped over his sister's son and caused the infant's death. 6

The sage called on his disciples to do penance to absolve him of his crime, yet none of them was willing. 7

Yājñavalkya then addressed his guru, 'Master, how can I do penance with these lazy, mediocre brahmins?' 8

His wise guru, enraged by this, replied to him, 'Forget all that you have learned from me. You're a failure as a brahmin! 9

You say these other brilliant men are mediocre, but what good are you, a follower who disobeys my words?' 10

Yājñavalkya said, 'I told you this in good faith, brahmin, but now I've had enough. This is what I've learned from you!' 11

\section{Parāśara:}

So saying, the sage vomited the blood-stained yajus prayers in physical form, handed them to his guru and walked away. 12

The other disciples all turned into partridges (tittira), brahmin, and gobbled up the prayers that Yãjñavalkya had disgorged. That's why these texts are known as Taittirīyas. 13

Those who performed penance for brahminicide at the urging of their guru became known as Caraka priests, on account of their undertaking (carana), best of sages. 14

But Yājñavalkya, who knew the art of breath control, Maitreya, wanted to win back the yajus prayers and devoutly worshipped Sūrya. 15

3 The Critical Edition reads samājenāgamiṣati. I have interpreted this as samāje nāgamisyati, which makes better sense. 


\section{Prayer to the Sun}

\section{Yājnavalkya:}

I bow to you, Savitr, door to liberation, whose brilliance has no measure. The Rg, Yajur and Säma Vedas are your three abodes; I bow to you. 16

In the form of fire and moon, you are the origin of the world, light-giving sun, pure energy and origin of the ray Saușumṇa. 17

I bow to you, one with the notion of time, consisting of kalā, kāsthth, nimesa and other measures. You should be contemplated as a form of Viṣnu; you are the syllable $O m .18$

You support the hosts of deities, having sustained the moon with your own rays, and the ancestral spirits with sweet nectarine libations. I bow to you, the essence of nourishment. 19

You bring cold and water, heat and rain, Lord, then take them away again. I bow to you who are three seasons, sun and arranger of all things. 20

You dispel darkness from the world and are its lord. You are the deity who is the abode of goodness. I bow to you, the brilliant sun. 21

Before you've risen, people are unfit for virtuous acts, nor does water purify. I bow to you, resplendent god. 22

Touched by your rays, the world is fit for rituals. I bow to you, the cause of purity. You are purity itself. 23

I bow to Savitr, the sun, light-bringer, the shining one. To Aditi's offspring, first of beings including gods and all the rest, I bow and bow again. 24

Your chariot is golden, your banners bestow nectar. I bow to you, the universal eye. 25

\section{Parāśara:}

After Yājñavalkya had praised the Sun with these and other words, the deity took the form of a stallion. 'Make a wish,' he said. 26

Falling to the ground, Yajiñavalkya besought the Sun, maker of the day, 'Give me those yajus prayers that even my guru doesn't know.' 27

Parāśara:

Hearing this, the lordly Sun bestowed on him the yajus prayers known as Ayātayāma, unknown even to his guru. 28 
Because the Sun in equine form revealed these prayers, brahmins who learn them are called Vājins, 'horse-possessors', best of brahmins. 29

The Vājins are divided into fifteen branches, all stemming from Yājñavalkya, Kanva and other blessed sages. 30

So ends Chapter Five in Book Three of the glorious Viṣnu Purāna.

\section{The branches of the Säma and Atharva Vedas; The purānas}

\section{Parāśara:}

Now hear of Vyāsa's student Jaimini, Maitreya, who duly arranged the branches of the tree-like Säma Veda. 1

Jaimini's son was Sumantu and his son was Sukarman. These two wise men each mastered one compilation. 2

Sumantu's son Sukarman created the Sähasra Sambitā, a compilation with a thousand verses. This was taken up by his two disciples, both adherents of great vows: 3

Hiranyanābha Kausalya and Pauṣpiñji, best of brahmins. The latter had fifteen disciples known as the northern singers of the Sama Veda. 4

The brilliant brahmins who received the fifteen compilations from Hiranyanābha are known by the wise as the eastern singers of that tradition. 5

Lokākṣi, Kuthumi, Kuṣīdin and Lāngali were Pauṣpiñji’s disciples. Their followers and their followers' disciples further raised the number of compilations. 6

Hiranyanābha's wise disciple, Kṛti by name, taught twenty-four compilations to his disciples. 7

They, too, split the Sama Veda into many branches. I'll now describe the compilations of the Atharva Veda. Sumantu was a brilliant sage. 8

He taught the Atharva Veda to his disciple Kabandha, who divided it in two and gave these to Devadarśa and Pathya. 9

Devadarśa's disciples included Maudga, Brahmabali, Śaulkāyani and Pippalāda, best of sages. 10 
Pathya had three disciples who also made compilations, brahmin: Jäjali, Kumudādi, with Śaunaka as the third, brahmin. 11

Śaunaka split his part in two and gave half to Babhru, and the second he gave to his follower named Saindhava. 12

Mañjakeśa further divided the Veda he received from Saindhava into two. Sections dealing with astrology, rules governing the sacrifice, mantras, 13

With incantations as the fourth and spells for dispelling evil as the fifththese are the major divisions of the Atharva Veda. 14

\section{The purāṇas}

Vyāsa, skilled in the import of the purānas, compiled these texts from myths and legends, verses and historical accounts. 15

The great sage then conferred this purānic compilation on his famous disciple, Romaharșana the bard. 16

Romaharṣaṇa had six disciples: Sumati, Agnivarcas, Mitrāyu, Śāṃśapāyana, Akṛtavraṇa and Sāvarṇi. 17

Akṛtavraṇa, scion of Kaśyapa, Sāvarṇi and Śāṃśapāyana were the creators of three root compilations, and Romaharșana's was the fourth. 18

This, the Viṣnu Purāna, is based on these four compilations, sage. 19

The first of all the purannas is said to be the Brabma, but eighteen are enumerated by experts in the field: 20

The Brabma, Padma, Viṣnu, Siva and the Bhāgavata. The Nārada is another, with the Marrkandeya as the seventh, 21

The Agni is eighth, Bhavisya the ninth, the tenth is the Brabmavaivarta and the Linga is eleventh. 22

The Varāba is the twelfth and the Skanda is thirteenth. The fourteenth is the Vamana, and the Kürma is the fifteenth. These are followed by the Matsya, Garuda and Brabmāṇ da purānas. 23

The first creation of the world, the subsequent re-creations, the genealogies of the patriarchs, the Manvantaras and accounts of royal dynasties are found in all these texts. 24

The purāna that I'm teaching you, Maitreya, is known as the Viṣnu and is listed after Padma. 25 
Lord Viṣnu is mentioned at every stage, including the creation, re-creation, genealogies, Manvantaras and the rest without exception, best of brahmins. 26

The four Vedas, the six Vedāngas, Mīmāṃsā, Nyāya, the purānnas and Dharma Śāstras make up the fourteen branches of knowledge. 27

The Ayur, Dhanur and Gändharva Vedas, with the Artha Śästra as the fourth, make eighteen in all. ${ }^{4} 28$

You should know that sages are of three descriptions: first are brahmin sages, then come divine sages and after them are royal seers. 29

Thus, I've described the branches of the Vedas and their subbranches, the creators of each and the reason they're divided. 30

The same division into branches is carried out in every Manvantara. 31

As the primal Veda is eternal, these branches are merely differences in appearance, brahmin. 32

I've told you all you asked about the Vedas. What else shall I tell you now, Maitreya? 33

So ends Chapter Six in Book Three of the glorious Viṣnu Purāna.

\section{How to escape death: Yama's song}

\section{Maitreya:}

You've told me precisely all I asked about, my guru, but please tell me one more thing I'd like to hear. 1

Seven continents, great sage, the underworlds and seven realms all lie within the egg of Brahmā. 2

This whole world is filled with living things: small, smaller and the smallest, as well as large, larger and the largest. 3

There's not one-eighth of an inch where living creatures, tied by bonds of karma, are not found, great sage. 4

4 The Vedāngas are supplements to the Vedas that cover phonetics, metre, grammar, vocabulary, astrology and recitation. Mīmāmsā and Nyāya deal with critical investigation of the Vedas and with logic. The Dharma Śāstras are legal texts, while the last four treat health, archery, performative arts and governance, respectively. 
Yet all fall prey to Yama, Lord of Death, and when their lives are at an end, master, he drags them off for torture. 5

And when they've been released from hell, they're born again among the gods or some other class of being, or so the scriptures say. 6

I'd like to hear about pure conduct by which we may escape from Yama's grip. Pray speak on this. 7

\section{Parāśara:}

Big-hearted Nakula once asked the same of his grandsire, so now you'll hear what Bhīṣma said to him. ${ }^{5} 8$

\section{Bhìsma:}

Long ago, a friend of mine, a brahmin from Kalinga, had come to visit me, dear boy. He said that he'd once asked this very question of a sage who knew his former lives. 9

That sage described the current state, and how things would be in future, and everything took place exactly as he foretold. 10

Filled with faith, I asked the brahmin more about it, and I've seen nothing anywhere that contradicts his words. 11

This is what he told me when I asked him long ago, recalling what that sage had said to him. 12

This man who recalled his former lives revealed to him a secret most profound. It was this dialogue between Lord Yama and his minion that I'll now repeat for you. 13

\section{The Kalingan:}

Seeing his minion with noose in hand, Yama whispered in his ear, 'Leave the devotees of Madhusūdana alone, for I'm the lord of all, except the Vaiṣnavas. 14

I was told by Brahmā, the disposer revered by hosts of gods, to govern (yam) every being in this world according to their deeds, both good and bad. But I myself am subject to my guru, Hari, and cannot act alone. When it comes to governance, Viṣnu is my superior. 15

5 Nakula is one of the five Pānd dava brothers. 
Just as gold is all one kind, but may be crafted into bracelets, bands and earrings, in that same way, Hari is present in all the deities, animals, mortals and the rest. 16

Just as drops of water, drawn from earth by wind, return to earth when the wind subsides, in that same way, deities, animals, mortals and the rest, separated on account of their impure qualities, are in the end united with that eternal being. 17

A mortal who understands this highest truth and bows to Hari, whose lotus-like feet are worshipped by the hosts of gods, is freed from all the bonds of sin. Avoid such persons, as you would a fire that's fed with oil, and continue on your way.' 18

When Yama's servant, noose in hand, heard his master's words, he asked the king of justice, 'Tell me, master, how shall I know a devotee of Hari, the arranger of the universe?' 19

\section{Yama:}

One who never strays from traditions of his community, who is equally disposed to friend and foe, who takes nothing, harms no-one and is pure of mind - know him to be a devotee of Viṣnu. 20

One whose self remains unstained by filth and folly in the age of Kali, whose thoughts are pure, always holding Janārdana in his heart when delusion ends-know him to be a faithful devotee of Hari. 21

One who finds another's hidden gold yet thinks it no better than a straw, and one whose heart is always set on the lord alone-know that fine being to be a devotee of Viṣnu. 22

Where, on the one hand, is Viṣnu, a mountain of purest crystal, and on the other, the selfishness and sundry faults that fill the hearts of men? The heat produced by blazing fires will not be found in webs of cooling moonbeams. 23

Vāsudeva always occupies the heart of one whose mind is pure, selfless, tranquil, of unblemished conduct, a friend to all, whose words are kind and beneficial and who resists the lure of fame. 24

When eternal Viṣnu dwells within a person's heart, he seems to all the world to be resplendent, as a śäla sapling's beauty betrays the splendid essence of the earth beneath it. 25 
Keep well away, my servant, from those whose sins have been assuaged by obligatory and voluntary acts of penance, whose hearts are daily fixed on Viṣnu and who are free from folly, selfishness and pride. 26

If Lord Hari, beginningless and eternal, bearer of the sword, the conch and mace, abides in a person's heart, his sins are destroyed by Viṣnu, conqueror of all misdeeds, for how can darkness reign when the sun is shining? 27

The eternal lord will not be found in the heart of one who steals another's wealth, who harms a living thing, whose speech is false or harsh, who's proud of shameful deeds or harbours impure thoughts. 28

Janārdana dwells not in the heart of the rogue who eyes another's wealth, the wicked man who vilifies the good, he who neglects the sacrifice or gives nothing to the worthy. 29

A deceitful man who begs a loan from his bosom friend, kinsman, spouse, son, daughter, father, mother or servant-recognise that such a lowly wretch is not a devotee of Viṣnu. 30

Of impure thought, attached to vice, ever smitten by the company of the vulgar and influential and who daily exerts himself in wicked ways-this bestial being isn't Vāsudeva's devotee. 31

'This whole world, including me, is Vāsudeva, the ultimate being, the highest lord, the One'-when such pure thoughts as these reach eternal Viṣnu in their hearts, let those people be and pass them by. 32

Keep well away, my servant, from sinless men who say, 'Lotus-eyed Vāsudeva, Viṣnu, supporter of the world, eternal bearer of the conch and discus, be my refuge!' 33

Don't go near that worthy man in whose heart the everlasting being abides, for he is destined for a realm that's different from mine, as my power is checked by Viṣnu's discus. 34

\section{The Kalingan:}

Such was the command that the god of death, the Sun's own son and lord of justice, made to his emissary. This is what the sage told me, and I've told you, best of Kurus, exactly what he said. 35

\section{Bhìsma:}

Thus spoke my friend in former times, Nakula, the kind-hearted brahmin from Kalinga. 36 
I've relayed the whole account to you, dear boy, as is fitting, since Viṣnu is the only means of rescue from the ocean of samsära. 37

The minions with their staves and ropes, Yama himself and the torments he inflicts, hold no fear for those whose inner self is always fixed on Keśava. 38

\section{Parāsara:}

In answer to your question, sage, I've retold in full this song of Yama, the Sun's own son. What further would you like to hear? 39

So ends Chapter Seven in Book Three of the glorious Viṣnu Purāna.

\section{The four communities}

\section{Maitreya:}

Tell me, master, how those who wish to flee samsāra worship the divine lord, the ruler of the world. 1

I'd also like to hear about the fruits of praising Govinda, sage, won by those intent upon such practices. 2

\section{Parāśara:}

The question you've just asked was also put to Aurva by Sagara, that great sage. Listen and I'll tell you what he said. 3

Bowing deeply, Sagara questioned Aurva, the scion of Bhrgu, about the perfect way to worship Viṣnu, best of sages, 4

And the benefits that people gain by doing so. Now listen to his reply, Maitreya. 5

\section{Aurva:}

When Viṣnu is praised, one gains one's wishes in this world, and then in heaven as sought by blessed ones, and finally supreme nirvāna. 6

One receives whatever reward of any size, great or small, that one desires, your majesty, when one worships everlasting Viṣnu. 7

Since you ask, ruler of the earth, I'll tell you how he's worshipped and the rewards that result therefrom, so listen: 8

Viṣnu, the highest being, is worshipped by a person who practises the traditions of his community; there's no other path that pleases him. 9 
The sacrificer worships him, as does one who offers prayers, sire. But harming others injures Hari, too, because he's everything. 10

Janārdana is therefore worshipped by any person of good conduct who follows the traditions and the practices set down for his community. 11

A brahmin, kṣatriya, vaiśya or śūdra, sire, who's intent upon his duties worships Viṣnu; there is no other way. 12

Keśava is pleased by one who doesn't curse or lie or slander, which might upset another being. 13

He is pleased by one who doesn't covet another's wife or goods, and never thinks of doing harm, your majesty. 14

Keśava's pleased by one who doesn't strike or kill a living thing, sire. 15

Govinda's pleased by one who's always keen to serve the gods, the brahmins and his guru, sire. 16

Hari's ever gratified by one who wants the welfare of all beings, as for his son or for himself. 17

Viṣnu's always pleased by one whose mind is free from faults like anger, and whose thoughts are without stain, your majesty. 18

One who undertakes the duties of his community and stage of life, as ordained by scripture, sire, worships Viṣnu; there is no other way. 19

\section{The practices of the four communities}

\section{Sagara:}

As this is so, I wish to hear about the duties of each community and stage of life. So, tell me all, you brahmin hero. 20

\section{Aurva:}

Listen well while I explain the duties of the brahmins, kṣatriyas, vaiśyas and śūdras in that order. 21

A brahmin, intent upon the study of the Vedas, should practise generosity and worship gods with sacrifices. He should always be supplied with water and maintain the sacred fires. 22

To earn a living, he may perform a sacrifice for others or do some teaching. He may accept donations as befits a brahmin because he is respected. 23 
He should act to benefit all beings and disadvantage none, because his greatest treasure is benevolence to everything. 24

A brahmin should be equally disposed towards a rock and to a jewel belonging to another man. It's also been prescribed that he approach his wife at the proper season, sire. 25

A kșatriya should willingly make donations to the brahmins, and such a king should offer various sacrifices and undertake the study of the Vedas. 26

Military life and defence of the realm are his principal occupations, but his primary duty is the protection of the world. 27

A king fulfils his duty by defending his dominion and, on that account, a portion of the merit of the sacrifice and other rituals accrue to him. 28

By punishing the wicked and protecting virtuous people, a king who keeps each order in its place attains the place in heaven that he desires. 29

Brahmā, universal grandsire, gave the occupations of animal husbandry, trade and agriculture to the vaiśya, sire. 30

Study, sacrifice and generosity are also duties ordained for him, as well as the performance of regular and occasional rites. 31

The súdra's intended duty is to serve the twice-born orders, and sustain himself thereby, or with income raised from trading or practising a craft. 32

The śūdra makes donations and offerings of cooked food, and performs each ritual for his forebears, or hires another to perform them for him. 33

Acquisition of wealth for the support of their dependants, approaching wives at the proper season, sire, 34

Compassion towards all creatures, patience, humility, truth, purity, resilience, cheerfulness, eloquence, 35

Friendliness, generosity and kindness are said to be the virtues for every order, sire. 36

These are also features common to every stage of life. Now hear about the virtues and the practices to be followed by brahmins and the others in times of strife. 37

It's said a brahmin may adopt the practices of a kṣatriya or a vaiśya in a crisis, and a vaiśya may adopt a kṣatriya’s ways, but neither a kṣatriya nor a vaiśya may adopt the practices of a śūdra if it's possible to avoid them, sire. 38 
If they must adopt another's ways in times of crisis, then they shouldn't mix the practices of different orders. 39

I've told you all about the duties of each community. Now listen while I describe the duties for each stage of life. 40

So ends Chapter Eight in Book Three of the glorious Vișnu Purāna.

\section{The four stages of life}

\section{Aurva:}

Once he's been invested with the sacred thread, sire, a boy should live in his guru's home as a devout brabmacārin, a celibate student, intent on mastering the Vedas. 1

Pure in conduct, he should serve his master, observe the vows and study with all his heart. 2

At dawn and dusk, he should devoutly venerate the sun, attend the sacred fire, your majesty, and pay homage to his guru. 3

He should stand when his guru stands, walk when he walks and sit below his guru when he sits. The disciple should do nothing to upset his master, best of kings. 4

When directed, he should chant the Veda before his teacher, with his mind on nothing else. With permission, he may eat the food received as alms. 5

He should bathe in water that his teacher used for washing, then bring him firewood, water and other requisites each morning. 6

When he's finally mastered the appropriate Veda and received his guru's blessing, having recompensed him fully, that learned man may then become a householder. 7

He should take a wife with proper rites and, having earned some money through his efforts, he should diligently fulfil the duties of that station, sire. 8

He should honour his ancestral spirits with oblations, the deities with sacrifices, guests with food, sages with recitation, the progenitor Brahmā with offspring, 9

All living creatures with offerings and all the world with kindness. Such a person reaches those heavenly realms that are won through one's own actions. 10 
Some wandering brabmacāins live on alms, after which they establish their own households. 11

These brahmins journey widely in accord with Vedic teaching, to bathe at sacred fords, master, and to see the world. 12

For those who roam with neither home nor food, finding shelter where they can at dusk, the householder offers sustenance and refuge. 13

To his home he welcomes guests with kindly words, sire, offering a bed, a seat and food to eat. 14

When a traveller turns with disappointment from a person's door, he leaves his misdeeds with the householder and takes that person's good luck with him. 15

In the homes of virtuous people, one meets neither disrespect, pride, deceit, regret, harm nor insult. 16

A householder who follows these noble precepts to the letter will be released from all his bonds and ascend to the highest realms. 17

In ripe old age, your majesty, a householder who has done his duty should venture to the forest, leaving his wife in the care of his sons, or he may take her with him. 18

There, that sage should live on leaves and roots and berries, his hair and beard and matted locks untended. He'll sleep directly on the ground, sire, welcoming all comers as his guests. 19

He'll fashion upper and lower garments from skins, or kāsa and kuśa-grass, your majesty. It's ordained that he should bathe three times a day. 20

It's prescribed that he should worship deities with fire sacrifices, sire, honour all who come as guests and offer food to mendicants. 21

It's ordained that he should rub his limbs with forest oils and, during his austerities, your majesty, he must endure the heat and cold and other trials. 22

The forest-dwelling sage who takes this course with self-restraint burns away his misdeeds like a fire, and wins the everlasting realms. 23

The fourth stage, that of mendicant, is mentioned by the wise, your majesty. Listen while I describe it. 24

One who sheds affection for his sons, possessions and his wife, sire, should begin the final stage of life, freed from all his selfishness. 25 
He should forsake the threefold goals-love, wealth and virtue-and other undertakings, your majesty, and be just as well disposed to friends and foe and other living things. 26

Restrained in voice and thought and deed, he'll not harm a wombborn being, or one that's hatched or any other, while renouncing all attachments. 27

He'll stay in a village for just one night, or in a city for five, lest he start to like or loathe them. 28

To support himself, he'll visit the homes of the first three orders to ask for food when the fires are out and the people fed. 29

Having cast off desire, anger, pride, delusion, greed and every other fault, he'll become a selfless mendicant. 30

A sage who roams without a threat to any creature is not threatened by them in turn. 31

The brahmin lights a sacrificial fire within his body and makes oblations to it through his mouth with any food that he has come by. With this body, a mass of fire, he proceeds to heavenly realms. 32

A stainless brahmin who attains the state of liberation that I've described, fixed on the thought of his own resolution, will reach the tranquil realm of Brahmā, which shines like a light that needs no fuel. 33

So ends Chapter Nine in Book Three of the glorious Viṣnu Purāna.

\section{Birth and marriage}

\section{Sagara:}

You've described the fourfold stages and the duties of each community, best of brahmins. Now I'd like to hear about the rituals folk perform. 1

Tell me all about the regular and occasional rites and those performed by people with a special need, outstanding Bhrgu, as you know it all, or so it seems to me. 2

\section{Aurva:}

I'll now describe the regular and occasional rites you've asked about, your majesty, so listen carefully. 3 
A father should perform the entire cycle of birth rituals, as well as a joyous sräddha, when a son is born. 4

He should offer food to pairs of brahmins facing east, sire, and, according to his means, sacrifice to the gods and ancestral spirits, as befits the twiceborn orders. 5

Filled with joy, he should offer riceballs mixed with yoghurt, dates and barley to the Nāndīmukha spirits, sire, with the tips of those fingers sacred to the gods, 6

or with the root of his little finger, sacrosanct to Brahmā. He should then perform all the rites and circumambulations to ensure the child will come of age, your majesty. 7

Following that, on the tenth day, the father should name the child. The first part should be a deity's name, and the second should befit a person, such as sarman or varman, 'prosperity' or 'defence'. 8

Sarman is said to be for brahmins and varman for kṣatriyas, while gupta and dēsa, 'protected' and 'servant', are best for vaiśyas and for śüdras. 9

He shouldn't choose a name that has no meaning, is unattested, vulgar, unlucky or unsuitable, and it should have an even number of syllables. 10

He should choose a name that's not too long or short. It shouldn't have too many long vowels but be easy to pronounce and end in a short vowel. 11

Following this, after the child has been blessed with successive rites, he should start his education in his guru's home in accordance with tradition, as I've described. 12

\section{Marriage}

Once his education is complete and he has recompensed his guru, your majesty, if he wants to be a householder, he should marry. 13

Alternatively, he may remain a brabmacārin, having taken fitting vows, and serve his guru, his guru's sons and dependants. 14

He may decide to be an ascetic in the forest or a mendicant. Whichever path he takes, sire, he should abide by his decision. 15

He should wed a girl one-third his own age, who's neither bald nor hairy, dark nor pale. 16 
He shouldn't wed a girl who was born a cripple, has extra limbs or is impure, hirsute, low-born or sickly, 17

Or wicked, rude or who inherited deformity from her father or her mother, 18

Who has signs of a beard or a mannish appearance or who mumbles, shrieks or whispers. Nor should he wed a girl who blinks too much or whose eyes are bulging. 19

Nor should he wed a girl with hairy legs, thick ankles or dimples in her cheeks when laughing. 20

A wise man should never wed a girl with rough skin, white fingernails, red eyes, pudgy hands or fat feet. 21

Nor should he wed a girl who's too short or tall, whose eyebrows meet, whose teeth protrude or have gaps between them. 22

In accordance with tradition, your majesty, a householder should wed a girl five degrees removed on his mother's side and seven on his father's. 23

Different forms of marriage are attributed to Brahmā, the deities, sages, patriarchs, demigods, gandharvas and rākșasas, with paišãcas as the eighth and vilest form. 24

One should marry according to whichever form great sages recommend for one's community, avoiding all the others. 25

When a man becomes a householder, he should wed a girl who practises virtue at his side. This custom, closely followed, yields magnificent rewards. 26

So ends Chapter Ten in Book Three of the glorious Viṣnu Purāna.

\section{Rituals of the householder}

\section{Sagara:}

I'd like to hear about the proper conduct of a householder, sage, adhering to which he'll never be excluded from this world or the next. 1

\section{Aurva:}

Listen, your majesty, to the marks of proper conduct. Anyone who follows these will conquer both the worlds. 2 
Sādhus are faultless, holy men. Sat is another word for $s \bar{a} d b u$, and the behaviour, ācāra, of such beings is called sat-ācāra, 'good conduct'. 3

The seven sages, Manus and patriarchs, sire, both taught and practised such behaviour. 4

The wise person wakes at the Brābma-mubürta, 'the hour of Brahmā', ninety minutes before the dawn, when his mind is clear, your majesty. When he's wide awake, he should meditate on virtue, prosperity and the obstacles to both. 5

He should also meditate on love in forms that don't conflict with other goals and should regard these threefold aims of life as equally important to overcome all obstacles, both visible and invisible. 6

He should abandon wealth and love if they conflict with virtue, sire, but may depart from virtue if it leads to misery or offends against society. 7

Following this, after rising in the morning, your majesty, he should venerate the sun. 8

Leaving the village in a south-westerly direction, he should relieve himself at a distance further than an arrow flies. 9

After washing his two feet, he should discard the dirty water in the courtyard of his house. 10

A wise man never urinates on his shadow or that of a tree or in the direction of a cow, the sun, a fire, the wind, his guru or a member of the twice-born orders. 11

Nor should he defecate or urinate on cultivated land, in a field of corn, a cow-pen, in an assembly, on a road, in a river or at a sacred ford, you bull among men, 12

Nor should he defecate or urinate in water, on a riverbank or cremation ground. 13

During the day, a wise man should urinate facing north, and at night the opposite direction, except in an emergency, your majesty. 14

Spreading grass on the ground and placing his clothes on his head, he shouldn't tarry or engage in conversation. 15

He shouldn't use earth from an anthill, or dug up by rats, or taken from water, or used by someone else for cleaning, or left over from plastering a house, 16 
Or cast up by worms or turned by a plough, sire, but should avoid these types of earth to clean himself. 17

He should use one handful of earth to clean his penis, three for his anus, ten for his left hand and seven for both hands, your majesty. 18

He should rinse his mouth with clear, odourless water, free from froth and bubbles. With a steadied mind, he should use more earth again. 19

When he's cleaned his feet and rinsed them, he should take three sips of water and wash his face twice over. 20

Next, he should splash water on the orifices of his head-the eyes, ears and nostrils - and on his crown, arms, chest and navel, sire. 21

When he's finished washing, he should tidy up his hair and place a tilak on his forehead before a mirror with a stalk of dīrvā-grass or something similar. 22

\section{Daytime rituals}

In accordance with the practices of his community, sire, he should start to earn some money to support himself and carry out the sacrifices, filled with faith. 23

Since these rituals, based on offerings of soma, foods and butter, are undertaken to bring folk wealth, he may try to earn a living from them. 24

Before conducting regular sacrifices, he should bathe in the water of a river great or small, a pool or mountain stream. 25

He may wash himself on land with water from a well, or with water brought for bathing from a nearby source. 26

After he has washed, donned fresh clothes and calmed his mind, he should make libations to the gods, the sages and ancestral spirits with those parts of his hand sacred to each. 27

He should make three libations of water to please the gods, the same for the sages according to propriety and one for Brahmā the progenitor. 28

He should also make three offerings of water to please his ancestral spirits, sire, including his grandfathers and great-grandfathers. 29

With his mind still focused, he should make offerings to his paternal grandmother, her father and his father with the forefinger sacred to each, and, if he so desires-listen to me- 30 
To his mother, maternal grandmother, her mother, his guru's wife, his guru, his maternal uncles and other kin, to his dearest friends and to the king, your majesty. 31

Once he has propitiated the deities and the rest, if he wishes, sire, he may recite this prayer and offer water for the benefit of all beings: 32

'Gods, demigods, yakșas, nāgas, gandharvas, rākșasas, paiśācas, guhyakas, siddhas, kūṣmāṇ des, trees, birds, 33

Those animals that live in water, on land or in the air-may all these beings be satisfied at once by this water that I offer. 34

This I do to benefit all those beings enduring torment in the hells. 35

Those who are my kin and those who aren't, those who were my kin in previous lives and any beings who desire an offering of water from memay they all be satisfied! 36

May these drops of water that I offer relieve those beings beset by thirst and hunger wherever they may be.' 37

A person may propitiate this whole world with the voluntary libations I've described, your majesty, and, having done so, may acquire the merit that arises from benefiting the world, blameless monarch. 38

Having duly made these offerings, filled with faith and taking water for himself, he should cup his hands and offer it to the sun: 39

'I bow to the shining one, the Absolute, the brilliant sun whose energy comes from Viṣnu, who enlivens the world, the pure stimulator who grants the reward of sacrifices.' 40

Following this, he should perform a domestic ritual, worshipping his tutelary deity with offerings of water, flowers, incense and the rest. 41

Before all else, he should perform a fire sacrifice for Brahmā. 42

He should reverently offer an oblation to the progenitor, the household deities, Kāśyapa and Anumati in succession. 43

He should then pour the remaining water as a libation to the Manika and Parjanya rain gods, at the door of his house to Dhātr and Vidhātṛ and at its centre to Brahmā. 44

Now, tiger among men, you'll hear about the household deities of the four directions. 45 
A prudent man should offer food left over from the sacrifice to Indra, Yama, king of justice, Varuna and Indu the Moon in the east and other directions in succession. 46

In the north-east corner, a wise person should scatter an offering of food for Dhanvantari, the heavenly physician, then offer some to Viśvadeva. 47

In the north-west corner, he should offer food to Vāyu, god of winds, then to each direction, to Brahmā, the sky and sun, which is the source of everything. 48

He should offer food to all the deities and other beings, the universal lords, ancestral spirits and Yakșman, god of tuberculosis, your majesty. 49

Bringing other foodstuffs, a wise person may make an offering with a focused mind to all the other beings on a clean patch of ground if he so desires. 50

'Deities, humankind, animals, birds, siddhas, hosts of yakșas, nāgas and Daityas, spirits of the dead, paiśācas, trees and all those who desire the food I offer, 51

Ants, worms, moths and other insects-hungry and bound by bonds of karma - may they all be sustained by this and may they all be happy. 52

I place this food upon the ground to nourish those who have no mother, father, family, sustenance or the means of preparing it, and may they all be satisfied and gladdened! 53

Since all creatures, this food, Viṣnu and I are one, I make this offering, a form of every being, to benefit them all. 54

Here I scatter food to nourish living beings of fourteen kinds and all the gathered hosts of creatures. May they all rejoice!' 55

Reciting this prayer, a person filled with faith should cast some food upon the ground to benefit each living thing, because the householder is the refuge of them all. 56

Following this, one may place some food upon the ground for dogs, birds, untouchables and other fallen and unworthy people. 57

\section{Hospitality}

After this, he should stand in the courtyard of his house for as long as it takes to milk a cow, or longer if he so desires, to wait for any visitors. 58 
He should warmly welcome any guest who comes, offer him a seat and allow him to wash his feet. 59

He should sincerely offer food and ask and answer questions in a civil manner. When the visitor departs, the householder should show respect by seeing him on his way. 60

He should also duly welcome any guest whose clan and name he does not know, who comes from far away or who lives in another village. 61

One who feeds himself but doesn't honour hungry guests who have no kin or come from a distant region goes to hell. 62

Without asking which branch of the Veda he recites, or about his lineage, religious practice or family, a householder should regard a guest as Brahmā, the deity born of the golden egg. 63

To benefit his ancestors, sire, he should accommodate one additional brahmin from the same locality as himself, whose conduct and lineage are known, in order to perform the five required sacrifices. 64

Taking a serve of grain, he should cry 'Come!', your majesty, and offer it to a brahmin who is expert in the Vedas. 65

He should also give three serves to mendicants and brabmacārins. The prudent man should give generously, in accordance with his wishes, if he can afford to do so. 66

One should honour these four as guests, including the mendicants mentioned earlier. By doing so, he acquits his debt to humanity and the sacrifice. 67

A guest who turns from a house to go elsewhere, his hopes frustrated, leaves his sins with the householder and takes that person's good luck with him. ${ }^{6} 68$ Brahmā the progenitor, mighty Indra, Agni, god of fire, the host of Vasus and the Sun are all present in the person of a guest, sire, and eat the food he eats. 69

That's why you should always do your best to honour guests. One who eats without offering food to guests will feed on suffering alone. 70

6 This is similar to verse 3.9.15. 
The householder should next give sanctified food to those daughters who still live with him, the afflicted, pregnant, elderly and the young, while he himself eats last. 71

One who dines before these others commits a grave misdeed and, when he dies, he'll go to hell and live on nothing but phlegm. 72

One who eats without bathing first will feed on filth; without a prayer, on pus and blood. One who eats unsanctified foods will drink urine, and one who eats before the young and others will swallow excrement. 73

Listen therefore, your majesty, to how a householder should eat, and how, when eating, he may avoid the bonds of sin. 74

And how in this life he may enjoy unequalled health, increased vigour, an end to strife and his enemies' demise, your majesty. 75

\section{The midday meal}

After he has duly bathed and propitiated the gods, the ancestors and sages, the prudent householder, wearing an appropriate gemstone on his finger, may eat, 76

But only after he's said his prayers, made an offering to the fire, changed his clothes, your majesty, and offered food to guests and brahmins, elders and dependants. He should wear some pleasant scent and a fitting garland, sire. 77 He shouldn't eat while wearing just a single robe, ${ }^{7}$ or while his hands or feet are wet, your majesty. With a clean and cheerful visage, he should face one cardinal point or other: 78

East or north are best. Let his mind not dwell on other matters, and let his food be fitting, wholesome and prepared with purest water. 79

Food should not be accepted from those of loose morality, be unattractive or unconsecrated. The householder should offer food to hungry students. 80 He may then dine cheerfully from vessels clean and suitable, your majesty. 81 He shouldn't eat from dishes on a stool, in an improper place, sire, or at improper times, or with a troubled mind, first having offered the best part to the fire. 82

7 A single garment would be something like a lungi, dhoti or sarong, while the upper garment would be shawl. The implication is, I think, that he should cover his chest. 
His food should be sanctified with mantras, be suitable and be fresh on the day, your majesty, except for fruit and meat and varieties of dried vegetables. 83

Dates and thickened treacle are also excepted, sire. He should never eat anything from which the essence has been extracted. 84

A discerning person should eat without leaving anything over, sire, except for honey, water, yoghurt, butter or barley grits. 85

With his mind on what he's eating, he should first take something sweet, then eat something sour or salty as the middle course, followed by pungent or astringent foods. 86

One who begins and ends a meal with liquids, taking solid food between, will never be deprived of health or strength. 87

One should take five mouthfuls of wholesome food like this, in silence, without complaint or conversation, in order to sustain himself. 88

When he's finished eating and rinsed his mouth, facing east or north, he should duly rinse his mouth a second time and wash his hands below the wrist. 89

Content, his mind at rest and seated comfortably, he should turn his thoughts to his tutelary deities. 90

'May fire, stirred by wind, reduce this food to earthy elements, and in the space that air provides, digest it, and may I be satisfied. 91

May this food, when digested, replenish the elements of earth, water, fire and wind within me, and may I enjoy unbroken happiness. 92

May this food vivify the five vital airs, prāna, apāna, samāna, udāna and vyāna, and may I enjoy unbroken happiness. 93

May the fires known as Agasti, Agni and Vaḍaā digest all the food I've eaten. ${ }^{8}$ May they grant me the happiness that arises from the digestion of that food, and may I be free from physical afflictions. 94

Viṣnu, primary being and universal lord, is embodied in all the senses and in everybody. By this truth, may all the health-giving food I've eaten be digested. 95

8 Vadavā or 'Mare's Fire' is found underwater or in the lower regions and is said to emerge from a cavity called the 'Mare's Mouth' in the southern ocean (from Monier-Williams 1899). 
Viṣnu is consumer, food and digestion. By this truth also, may all the food I've eaten be digested.' 96

Having made this prayer, one should rub his stomach with his hand, then eagerly devote himself to relaxation. 97

\section{Dusk: The sandby $\bar{a}$ rituals}

One should spend the remainder of the day engaged in pastimes endorsed by proper scriptural authority and which don't conflict with the path of virtue, after which one should perform the sandhya rituals with devotion. 98

At day's end, a wise person should duly undertake these rites as the sun goes down, and in the morning before the stars have faded, having properly rinsed his mouth, your majesty. 99

The two sandhyā rituals should always be performed, sire, except when a baby is being born or at a time of impurity, anxiety, illness or danger. 100

One who rises after the sun, or retires before it sets, is obliged to perform some penance, unless he is unwell. 101

Having risen before the sun, sire, one should perform the sandbya ritual, and, before he sleeps, the ritual suited to the dusk. 102

Wicked folk who fail to offer these at dawn and dusk go to Tămisra, the hell of darkness, sire. 103

In the evening, furthermore, a householder's wife should offer food to the Viśvadevas without a mantra, sire. 104

At that same time, she should scatter food for dog-eating svapacas and other untouchables. 105

A wise person should hospitably honour a guest who arrives at that hour, to the best of his ability, with water for washing his feet, a seat, a polite bow and words of welcome. He should then offer him food and a bed, your majesty. 106

The sin of turning back a guest arriving after sunset is eight times greater than that of refusing one who comes in daylight, sire. 107

One should therefore honour guests who come at night with every effort, sire, as when such guests are welcomed, all the gods are honoured. 108

One should try to please a guest as much as possible by offering rice, vegetables, water, a bed, a mattress or just a place on the floor. 109 


\section{Night: Marital relations}

In the evening, when he has washed his feet and all his body, and has finished dinner, sire, the householder should retire to a sturdy wooden bed. 110

He shouldn't sleep on one that's narrow, broken, uneven, dirty, buginfested or lacks a bedspread. 111

They recommend that he should sleep with his head to the east or south, sire, as any other direction is unhealthy. 112

It's also recommended that a man approach his wife at the proper season, sire, under an asterism with a masculine name, at an auspicious hour and on even nights. 113

One should not approach a woman who hasn't washed or is unwell, menstruating, unattractive, angry, unsuitable, pregnant, 114

Unskilled, has another lover, is not affectionate, is the wife of another man, is hungry or has overeaten. He himself should have these qualities: 115

Having bathed, and wearing garlands and some fragrance, he should show affection, being neither full nor hungry, and approach intercourse with love and passion. 116

On the eighth and fourteenth days of the lunar month, and on days of the new and full moon, sire, and when the sun first enters a sign of the zodiac- 117

A person who enjoys oil, women or meat on these days proceeds after death to a hell realm where he'll feed on excrement and urine. 118

On all such days, therefore, wise, self-restrained men devote themselves to holy scripture, divine sacrifice, meditation and prayer. 119

There should be no intercourse in a vagina other than a woman's, or in an orifice other than a vagina, or under the influence of drugs, or in the home of a deity, brahmin or guru, 120

Or at sacred sites, public squares, riverbanks, assembly rooms, crossroads, cremation grounds or in groves or water, sire. 121

A wise person should avoid intercourse during all the days I mentioned and during twilight, sire, or he'll be punished with urine and faeces in the next world. 122 
Intercourse at any of these times is unproductive, and during the day it's simply wrong, your majesty. Sex on the ground makes people sick, and sex in the water is not recommended either. 123

One should never approach another man's wife for intercourse, or even contemplate it, let alone discuss it with her, as this will weaken his bones and joints. 124

One who has enjoyed the wife of another man will be punished in both worlds: in this, his life is short, and in the next, he'll go to hell. 125

Bearing all this in mind, a wise man may approach his wife in season, when she is free from all the states I've mentioned and if she's in the mood, even if the timing is not exactly right. 126

So ends Chapter Eleven in Book Three of the glorious Viṣnu Purāna.

\section{The cond uct of the wise}

\section{Aurva:}

The householder should worship gods, cattle, brahmins, holy men, the elderly and his teachers. Twice a day he should perform the sandbya rituals and fire sacrifices. 1

A prudent person should always wear garments that have no holes, take medicine as recommended and carry gemstones for protection. 2

With clean and freshly pomaded hair, a man should always wear a pleasant scent and dress in tasteful garments with attractive garlands of white flowers. 3

He should never take another's property, or make the slightest harsh remark, but should speak politely and truthfully, without mentioning another person's faults. 4

He shouldn't covet another man's wife, nor seek enmity with him, sire, nor should he ride in an unsafe vehicle or rest in the shade of an overhanging cliff. 5

Those who are odious, wicked, drunk, aggressive or louse-infested, prostitutes and their clients, the lowly, liars, wastrels, slanderers and cheats- 6 
A wise person should befriend none of these, nor should he travel with them alone. 7

He should never dive into a fast-flowing river, sire, or enter a burning house or climb to the top of a tree. 8

He shouldn't grind his teeth, pick his nose or yawn without covering his mouth, and he should try not to sigh or cough. 9

A wise person shouldn't laugh raucously, break wind loudly, bite his nails, snap off stalks of grass or scratch the ground. 10

A wise man doesn't chew his beard or crumble clods of earth. He doesn't look at auspicious heavenly bodies when he's impure, master, 11

Or at another man's wife when she is naked, or at the setting sun. He shouldn't express disgust when he sees a corpse, because the odour of the dead arises from the moon. 12

At night, he should always avoid crossroads, sacred trees, groves near cremation grounds and the company of immoral women. 13

A wise man never oversteps the shadow of a sacred object, a deity, a brahmin or a heavenly body, nor should he enter a lonely forest by himself or sleep in a vacant house. 14

He should avoid hair, bones, thorns, filth, food offerings, ashes, chaff and places splashed with other people's bathwater. 15

A wise person should never seek refuge with unworthy folk or amuse himself with rogues. He shouldn't approach wild animals, nor should he dawdle when he rises in the morning. 16

A prudent person wastes no time when waking up or turning in, or when standing, sitting, lying down or working, sire. 17

He should keep clear of animals with tusks and horns, your majesty, and avoid frosts, thunderstorms and heat. 18

A wise man never bathes or sleeps or drinks water while he's naked, nor should he drink anything or worship deities if the top of his lower garment is loose. 19

He shouldn't perform a fire sacrifice, worship the deities, undertake any other ritual, rinse his mouth, make a speech or recite a prayer while wearing just a single garment. 20 
He should never sit with those who misbehave; decent people shouldn't spend as much as half a moment in such company. 21

A wise man never quarrels with superiors or inferiors, sire-marriages and arguments are best conducted between equals. 22

A wise man shouldn't start an argument but avoid pointless hostility; a little loss may be endured, but the wise reject the wealth that's won with aggravation. 23

After bathing, a person shouldn't wipe his limbs with a towel or with his hands or shake his hair or rinse his mouth before he's standing. 24

He shouldn't sit cross-legged in the presence of important people or stretch his legs towards them. He should kneel with modesty when he's with his guru. 25

He shouldn't pass auspicious or holy places or crossroads on the left, nor should he pass inauspicious ones on the right. 26

An educated person does not spit, defecate or urinate while facing the moon, fire, the sun, water, the wind or important people. 27

He shouldn't urinate while standing on a road, nor should he ever step over mucus, excrement, blood or urine. 28

Clearing the throat and blowing the nose are not recommended at mealtimes, when making food offerings, during other auspicious rituals, prayers or fire sacrifices or in the presence of important people. 29

A prudent man should never disrespect women, but neither should he trust them. He shouldn't be impatient with them, but neither should he grant them authority. 30

A wise person who is attentive to correct conduct shouldn't leave his house, your majesty, without respectfully acknowledging the sacred images, flowers, gems, sacrificial butter and venerable persons inside it. 31

He should be circumspect at crossroads and attentive towards sacrifices at the proper season. He should assist virtuous people in distress and seek the company of the learned. 32

One who venerates the deities and sages with devotion, who offers food and water to the spirits, and who welcomes guests hospitably, may reach the highest realms. 33 
A restrained individual whose speech is beneficial, measured, kind and timely, sire, will reach those worlds that are the source of everlasting happiness. 34

One who is intelligent, modest, patient, devout and polite, and who respects wisdom, worthy people and his elders, will proceed to peerless realms. 35

A wise man shouldn't study Vedas when there is unseasonal thunder or anything inauspicious, or on days when he's impure or during an eclipse. 36

Heaven is the least reward for that good man who calms the angry, who treats each person as his kin, who is selfless and who reassures the timid. 37

One concerned for his own welfare should carry an umbrella in rain or shine, a stick at night or in a forest and should always wear sandals. 38

A wise man shouldn't look up, to either side or in the distance when walking, but should keep his eyes on the ground two paces in front of him. ${ }^{9} 39$

The restrained man who shuns each cause of wickedness will never know the slightest diminution of virtue, wealth or love. 40

Sinless in the presence of the sinful, a kindly word upon his lips, a heart that's filled with benevolence-such a man holds liberation in the palm of his hand. 41

The world is upheld by the dignity of those who are always free from passion, beyond the reach of lust and greed and anger and firmly set on perfect conduct. 42

A wise person, therefore, speaks the truth when it's pleasing to another, but when the truth is painful, he stays silent. 43

He shouldn't speak if he thinks his words are merely pleasant but unhelpful. It's better to offer something beneficial even if it's hard to hear. 44

A wise man strives with body, voice and mind for the benefit of living beings in this world and the next. 45

So ends Chapter Twelve in Book Three of the glorious Viṣnu Purāna.

9 The text says 'the length of a yoke' in front of him. 


\section{Rituals relating to birth and death}

\section{Aurva:}

When a son is born, it's recommended that a father bathe himself fully clothed, after which he should undertake those rituals pertaining to the birth and a śräddha befitting the occasion. 1

After he has respectfully circumambulated the deities associated with even days and the ancestral spirits, he should honour brahmins and offer food with his mind on this and nothing else. 2

Facing east or north, he should offer food such as yoghurt, whole grains of barley and dates with that part of his hand or body sacred to each deity, your majesty. 3

As the host of ancestral spirits known as the Nāndīmukhas are propitiated by this śräddha, sire, it should be performed by people at all such happy times. 4

At the marriage of a son or daughter, on entering a new house, at the naming ceremony of a child, at the first cutting of the hair and so on, 5

At the parting of a pregnant woman's hair and at the first showing of a baby's face, the faithful householder should venerate the host of Nāndimukhas. 6

I've described in brief a set of rituals for the ancestors to be conducted on occasions marked by joy. Now you'll hear about the rules for undertaking funerals, your majesty. 7

After the corpse has been washed with fresh water and garlanded with flowers, it's cremated outside the village. The relatives of the deceased should immerse themselves in water fully dressed. 8

Facing south, they offer water in cupped hands, saying, 'This is for you, wherever you are.' 9

Entering the village with the cows when the stars begin to shine, they should sleep on straw mats spread on the floor. 10

Every day, they should place food on the ground as an offering for the deceased, your majesty. They may eat boiled rice during the day, but no meat, you bull among men. 11

Brahmins are to be fed for as many days as the mourner sees fit, for the deceased person is also nourished when his kin are dining. 12 
On the first, third, seventh and ninth days, having changed his clothes and washed himself outdoors, he should make an offering of sesame seeds and water. 13

On the fourth day, the bones and ashes should be gathered, sire, after which the bodies of those who make offerings of food may be touched again. 14

Those who made offerings of water are also able to resume all their usual activities, but should refrain from luxuries, such as garlands and body lotions, sire. 15

Those who made food offerings are permitted to use beds and seats after the deceased's ashes and bones have been gathered, but sexual intercourse with women is forbidden. 16

If the deceased is a child, or in another place, or is a fallen person or a sage, purity returns more quickly, and the rituals involving water, fire and so on are discretionary. 17

The food of a family whose relative has died may not be eaten for ten days, and the giving and receiving of gifts, sacrifice and Vedic studies are suspended. 18

Such are the rules when the deceased is a brahmin. For a kṣatriya, impurity persists for twelve days; for a vaiśya, two weeks; but for a śūdra, purity returns only one month later. 19

One might choose to feed the brahmins on odd days, and on each following day, one should place an offering of food on a bed of kusa-grass for the spirit of the deceased, along with any leftovers. 20

As soon as a man has fed the brahmins, he should touch some water, a weapon, a goad or stick, depending on his community, as he'll be purified by doing so. 21

After this, a man may resume his occupation as befits the brahmin order and the others, so he might live on earnings from a fitting source. 22

In every month that follows, the ekodista ceremony should be undertaken on the date of death, but rituals such as invocation of the deities are unnecessary. 23

A single offering of water should be made on these occasions to purify one person. A food offering should be made for the deceased, while brahmins take a meal. 24 
The brahmins who perform the sacrifice are to be asked if they are satisfied, and, if they are, then the words, 'May he also be eternally so', should be addressed to the deceased. 25

The practice known as ekodisțta takes place for one year after death, and an offering of food is made on such occasions. Now you'll hear some more about this, sire. 26

In the performance of this ritual, a set of four vessels filled with sesame seeds, fragrances and water is used, your majesty. 27

One is for the deceased, while the others are for the ancestors. The contents of the first are poured into the other three. 28

When the deceased has reached the status of an ancestor by this process, sire, one should venerate the old ancestral spirits with all the śräddha rituals. 29

A son, grandson, great-grandson, other relative, a brother's descendant or a descendant related through participation in a food-offering ritual are all entitled to perform these funerary rites, your majesty. 30

In the absence of all these, a descendant related through shared participation in a water offering, or a relative connected through a food or water offering on the mother's side, may officiate. 31

If the male line is extinct on both sides, these rituals may be performed by women, sire. The rites may even be performed by the deceased's acquaintances. Further, the king himself may cause the rites to be performed with wealth left by a person without heirs. 32

Funerary rites are of three kinds: initial, medial and final. Now you'll hear from me about the differences among them. 33

The initial rites are those performed after the cremation and the touching of water, a weapon and so on. The ekodista rituals performed in months that follow are known as medial rites. 34

The rituals after the food offering for the deceased, during which he acquires the status of an ancestral spirit, are called the final rites, your majesty. 35

The initial rites should be performed by those connected through a food or water offering on the father's or mother's side, or by the deceased's acquaintances or by the king when he has taken over the property of the deceased. 36

The final rites are performed by the deceased's son or his descendants, the deceased's daughter's sons or by their descendants, sire. 37 
The final rite of ekodista should also be performed each year by women on the anniversary of the death, your majesty. 38

For this reason, you should hear about these final rites, sire, the times at which they are performed and the procedure to be followed, flawless monarch. 39

So ends Chapter Thirteen in Book Three of the glorious Viṣnu Purāna.

\section{The śrāddha ritual for the ancestral spirits}

\section{Aurva:}

Brahmā, Indra, Rudra, the Aśvins, Sūrya, Agni, the Vasus, Maruts and Viśvadevas, the hosts of sages, humankind, beasts and birds, 1

Things that creep and crawl, ancestral spirits and all other beings - a faithful individual who performs a śräddha nourishes this whole world. 2

A man should undertake a śräddha on the fifteenth day of the dark fortnight each month, your majesty, and on the eighth day, or at any other time he wishes. Listen to me: 3

A householder should perform this ritual when he feels that an occasion worthy of a sräddha has arisen, or when a distinguished brahmin arrives. On the day of the new moon, or when the sun crosses the celestial equator, 4

At the equinox, at an eclipse of the sun or moon, when the sun first enters a sign of the zodiac, your majesty, 5

When an asterism or planet becomes inauspicious, when he has a nightmare or when the grain harvest begins, he may perform a discretionary śä́ddha. 6

The hosts of ancestral spirits are nourished for eight years by a srä ddha performed on the day of the new moon in the lunar mansions of Anurādhā, Višákhā and Svāti. 7

When the ancestors are honoured on the new-moon day in the mansions of Pusya, Raudra or Punarvasu, they are sustained for twelve years. 8

On the day of the new moon in Dhanișthā, Pūrvabhādrapadā or Śatabhiśak, the ancestral spirits, desiring nourishment, receive as much as even deities rarely do. 9

Now hear more about the śräddhas conducted on new-moon days in these nine mansions, and which afford such satisfaction to the ancestors, sire. 10 
Brahmā's son Sanatkumāra sang this song to great Purūravas, son of Ilā, who, bowing with respect, had asked about the śräddhas, and who was devoted to his ancestors: 11

\section{Sanatkumāra:}

The third day of Vaišākha, the ninth in the bright fortnight of Kārttika, the thirteenth in the dark fortnight of Nabhas and the fifteenth day of Māgha- 12

These four, the Yugädya, or 'first days of the age', are said to be endlessly auspicious, your majesty. Eclipses of the sun and moon, the eighth day of the three months of Agrahāyana, Māgha and Phālguna and the two days on which the sun crosses the celestial equator -13

On these occasions, a dutiful man should offer water mixed with sesame to the ancestors. This is equal to a sräddha of a thousand years, and the ancestors declare this rite is secret. 14

Whenever the fifteenth day of the dark fortnight of Māgha comes into conjunction with the constellation Śatabhișaj, presided over by Varuna, this is the best time for a sräddha, sire, as the benefit for the ancestors is not inconsiderable. 15

Food and water offered by individuals born at the time of a conjunction with the constellation Dhanișthā, sire, will satisfy the ancestors of their families for ten thousand years. 16

If a sräddha is performed when the conjunction occurs in the Former Bhādrapadas, the ancestors experience deepest satisfaction, and will be able to repose for an entire age. 17

A person who venerates the ancestors with respect, having first bathed in the Gañgā, Śatadrū, Vipāśā, Sarasvatī or the Gomatī at Naimișa, casts off all his sins. 18

The ancestors always sing this song: 'Having enjoyed a year of unalloyed satisfaction from water offered by our descendants at the end of the dark fortnight in the month of Māgha at a sacred ford, let us be satisfied again.' 19

The abovementioned rites undertaken at an appropriate time with pure devotion on behalf of a suitable recipient will enable everyone to achieve their wishes, unbroken prosperity and all else they might desire. 20

Now you'll hear from me the verses sung by the ancestors. Listen carefully and all this will come to pass. 21 
'The prudent man who undertakes food offerings for us, and doesn't try to hide his wealth, may be reborn a fortunate being in our own lineage. 22

If a man, when rich, gives wealth in the form of jewels, garments, lands, carriages or other great luxuries to brahmins for our benefit, 23

Or gives food according to his capacity at such a time with his heart filled with faith and devotion, and if he entertains the foremost brahmins, then he'll receive such wealth in equal measure. 24

If he cannot offer food, let him give to eminent brahmins as much uncooked grain as he is able, or even a little sacrificial fee. 25

If even that lies beyond his means, your majesty, he should bow down before a brahmin and offer him as many sesame seeds as he can hold on the tip of one finger. 26

Or, bowing with devotion, he may offer us seven or eight sesame seeds on the ground, along with water from his cupped hands. 27

If even that's not possible, the devotee may gather enough fodder for just one day from somewhere, and, bowing to us, filled with piety, he should feed it to a cow. 28

If none of these is possible, he must go to the forest and, raising his arms to salute the sun and the guardians of the four directions, he should recite this verse aloud: 29

"I have no possessions, wealth or anything else with which to express my faith. I bow down to my ancestors. May they be satisfied with these two arms, which I've raised with devotion in the path of the wind."' 30

\section{Aurva:}

Such is the song the ancestral spirits sang, and which befits times of both wealth and poverty. One who undertakes a śräddha should follow this prescription, sire. 31

So ends Chapter Fourteen in Book Three of the glorious Viṣnu Purāna.

\section{Conducting a śrāddha}

\section{Aurva:}

Now you'll hear about the ranks of brahmins to be offered food when a śräddha is conducted: 1 
One who knows the three Nāciketas, three Madhus or three Suparnas, ${ }^{10}$ the six Vedic supplements or the Vedas themselves; a scholar; an ascetic; one who chants the Jyeșțhasāman; 2

An officiating priest; the householder's sister's son, daughter's son, son-in-law, father-in-law or maternal uncle; one who practises austerities or maintains five sacred fires; the householder's students or relatives; and one who is devoted to his mother and father. 3

The householder should first engage the brahmins mentioned above in a śräddha, sire, in order to nourish his ancestral spirits, while others may be employed for less important rituals. 4

A false friend, a person with bad fingernails, one who is impotent, a brahmin with discoloured teeth, one who has sexually assaulted young women, one who has abandoned his sacred fires or Vedic studies, one who sells soma, 5

A person accused of a crime, a thief, a slanderer, one who performs sacrifices for villagers, one who teaches sacred texts to his servants or learns such texts from them, 6

The husband of a woman who was previously married, one who has abandoned his mother and father, one who supports the children of a suüdra or who is married to one, 7

One who lives off offerings made to an idol—none of these is worthy of an invitation to a śräddha. 8

On the first day, the prudent man should welcome outstanding scholars and other dignitaries and should explain to them his intention with regard to his ancestors and the deities. 9

After this, the initiator of the sacrifice, together with the brahmins, should refrain from anger, sexual intercourse and other business, as these are major obstacles to the ritual. 10

If a man who holds a śräddha, having begun to eat or having fed the brahmins whom he tasked with the ritual, then has sexual intercourse, he will cause his own ancestors to drown in a pool of semen. 11

First inviting eminent brahmins, as I mentioned, he should also offer food to any pious members of that order who arrive at his home unexpectedly. 12

10 Nāciketa, Madhu and Suparṇa appear to be different parts of the $R g$ Vedic corpus. Authorities differ as to the precise details. 
He should welcome all such individuals who come to his door with water for their feet and so on. 13

With blades of kusa-grass in his hands, he should offer them water to drink and invite them to be seated-an odd number of brahmins for an ancestral śräddha, and an even number for rituals for the deities, or as he wishes. 14

He may also engage a single brahmin for both the deities and his ancestors. 15 Filled with devotion, he should perform a śäddha for his maternal grandfather, which incorporates the worship of the Viśvadevas, or he may perform a ritual specifically for them. 16

He should offer food to those brahmins engaged for the deities, or those engaged for both paternal and maternal ancestors, while they are facing east, and to those engaged solely for his paternal ancestors, while facing north. 17

Some say that śāddhas for paternal and maternal ancestors should be undertaken separately, sire, while other famous sages say they may be held together and with the same offerings of food. 18

After spreading kusa-grass upon the ground and duly welcoming brahmins with hospitality, the wise man should, with the brahmins' permission, call upon the deities. 19

He should welcome them with grains of barley and some water, having offered garlands, perfumes, incense, lamps and other things, in accordance with tradition. 20

He should also offer these, placed on the left, to his ancestors, having first obtained permission from the brahmins and after spreading two layers of darbha-grass. 21

The wise man should then invoke the deities, preceded by mantras, sire, and on the lefthand side should make an offering to them with sesame and water. 22

At that time, again with the permission of the brahmins, sire, he should willingly offer food to any hungry traveller who arrives. 23

Ascetics, who appear in various forms to do folk favours, wander about the world disguised. 24

For this reason, a prudent man should always welcome visitors when a śra ddha is conducted, sire, for when a guest is deprived of hospitality, the outcome of the ritual is imperilled. 25 
With permission from the brahmins, the householder should then offer three handfuls of plain, unsalted food into the fire, you bull among men. 26

He should first say, 'Svāha to the fire, bearer of the offering!' Thereupon, your majesty, he should make an offering to Soma, the Moon, who nourishes ancestral spirits. 27

The householder should then make a third offering to Vaivasvata, the Sun's own son, after which he places a portion of the remnant food in the brahmins' bowls. 28

He should then offer the brahmins some delicious, highly desirable, carefully prepared food, with the polite invitation, 'Please enjoy this at your leisure.' 29

The brahmins should happily partake of this meal attentively, in silence and with cheerful smiles. It should be served without anger or haste, but rather with devotion. 30

Having uttered mantras to ward off rākșasas and scattered sesame on the ground, the householder should then regard the leading brahmins as his own forebears. 31

'May my father, grandfather and great-grandfather, in the form of these brahmins, be satisfied today. 32

May my father, grandfather and great-grandfather be satisfied, their bodies nourished by this offering made into the fire. 33

May my father, grandfather and great-grandfather be satisfied with the food I've scattered on the ground. 34

May my father, grandfather and great-grandfather be satisfied by this offering I've made here with devotion. 35

May my maternal grandfather, his father, his father and his father be satisfied. May all the deities achieve highest satisfaction, and may all evil spirits be dispelled. 36

May the master of the sacrifice, Hari, the everlasting lord, enjoy all the offerings I've made here. May all rākșasas and demons be gone at once from the vicinity of this sacrifice.' 37

When the brahmins have been satisfied, the householder should scatter leftover food upon the ground and offer every brahmin some water to rinse his mouth. 38 
With the permission of the well-fed brahmins, and with careful attention, he should place an offering of food mixed with sesame seeds on the ground. 39

With the part of his hand sacred to the ancestors, he should offer water in his cupped hands to his maternal forefathers, and with the same part of his hand, make an offering of food. 40

On a mat of darbha-grass with its tips pointing south, he should place the first food offering for his own father, consecrated with flowers, incense and so on, next to the leftover foods. 41

He should then make a second offering to his grandfather, and another to his great-grandfather. He should then satisfy his distant ancestors by scattering remnants of food wiped from his fingers on to the roots of the grass. 42

Having honoured his maternal ancestors in the same manner with offerings of food accompanied by incense and garlands, the householder should again give the leading brahmins water with which to rinse their mouths. 43

Thinking of them alone, sire, he should first make offerings to the ancestors with devotion, and then, requesting their benediction, while uttering 'susvadha', he should give gifts such as he can afford to the brahmins. 44

After he has given gifts to the Viśvadevas, he should address these words to them: 'May those who are Viśvadevas be pleased with this offering.' 45

When the brahmins have replied 'So be it', the householder should request their benediction, wise sovereign, after which he should first dismiss the ancestral spirits and then the deities. 46

The offering of food, the giving of gifts in accordance with one's capacity and the dismissal-all these follow the same order for both maternal ancestors and the deities. 47

From the initial washing of the feet to the dismissal of the gods and brahmins, the householder should make offerings first to his paternal and then to his maternal ancestors. 48

He should send the brahmins off with kind words, having paid them due respect, and then accompany them to the gate, after which, with their permission, he may return. 49

The wise man should then perform the usual ritual, the so-called vaisvadeva rite, for all the deities. He may then enjoy a meal together with respected individuals, his dependants and relations. 50 
In this way, a wise man should conduct śräddha rituals for his paternal and maternal ancestors. Nourished by such śräddhas, his ancestors will grant his every wish. 51

Three things have purifying power at a śräddha: one's daughter's son, a cashmere blanket and sesame seeds. There is also the giving, naming and displaying of silver. 52

A person offering a śräddha should eschew anger, wandering and haste, sire, as these three are not recommended for those who take part in this ritual. 53

The Viśvadevas, the paternal and maternal ancestors and the entire family of those who perform a śräddha are nourished, sire. 54

The host of ancestors is supported by the moon, and the moon is supported by ascetic practices. That's why, your majesty, it's recommended that ascetics be engaged to undertake a śräddha. 55

If just one ascetic stands before a thousand brahmins, sire, he will lead all participants, including the initiator, to the further shore. 56

So ends Chapter Fifteen in Book Three of the glorious Viṣnu Purāna.

\section{6. Śrāddha offerings}

Aurva:

An offering of fish or the flesh of a hare, bird, pig, goat, black antelope, deer, wild ox, 1

Sheep or cow-each of these nourishes the ancestors for one month longer than the offering named before it, but they will be satisfied forever with the flesh of the leather-billed bird, the vādbrinasa. 2

The flesh of a rhinoceros, sacred basil and honey are highly recommended for these offerings, sire, as they, too, provide eternal nourishment. 3

The life of one who undertakes a śrāddha at Gayā is fulfilled, sire, because it nourishes his ancestors. 4

Small-grained rice, wild rice, sorghum of both kinds and forest herbs are all fit for a srä ddha, you bull among men. 5

Barley, foxtail millet, black lentils, wheat, rice, sesame, cowpeas, kodo millet and mustard seeds are also suitable. 6 
The householder should not use grain unconsecrated at the time of the first harvest, sire, or black-eyed peas, proso millet or garlic. 7

Bottle gourds, red or brown onions, wild carrots, gandhāraka, groats, sea salt, rock salt, 8

Any reddish gums and other substances resembling salt-these are best avoided for a siäddha, along with other substances that have not been recommended. 9

Water that was drawn at night, or isn't fresh, sire, or is insufficient to satisfy a cow, or smells unpleasant or is frothy is unsuitable for a śräddha. 10

During the performance of a srä ddha, one should avoid the milk of animals whose hooves are not cloven, including camels, sheep, deer and buffalo. 11

A eunuch, outcaste, untouchable, heretic, drunk, invalid, rooster, dog, naked person, monkey, village pig, 12

Menstruating woman or a woman who has recently given birth-neither deities nor ancestors will accept a śräddha observed by any of these. 13

The devout individual should therefore conduct a śrāddha in an enclosed space and should drive off evil spirits by strewing sesame on the ground. 14

Food should not be rotten, contaminated with hairs, insects or anything else, sire, or be mixed with substances that lead to fermentation, but must be fresh. 15

Food offered by the faithful to the ancestors, while intoning their names and lineages, is sustenance for those very beings. 16

The following song was sung by ancestors long ago, your majesty, and was heard by Manu's son Ikșvāku in the grove of Kalāpa: 17

'May those who come to Gayā to make food offerings, out of respect for us, be reborn in our lineage as followers of the true path. 18

May one who offers us rice pudding with honey and butter on the thirteenth day of Bhādrapada or Maghā be reborn in our lineage, 19

Or when he marries a fair girl, or liberates a black bull or performs a horsesacrifice in accordance with the rules and with the proper recompense.' 20

So ends Chapter Sixteen in Book Three of the glorious Viṣnn Purāna. 


\section{The protection afforded by the Vedas; Viṣnu's phantom}

\section{Parāśara:}

This is precisely what holy Aurva told the great sage Sagara, Maitreya, when he asked about good conduct long ago. 1

Now I've told you everything, brahmin. One who strays from this will never win success. 2

\section{Maitreya:}

I know about the eunuchs, outcastes, menstruating women and the others, master, but I'd like to hear some more about the naked ones. 3

Who goes naked, and what acts lead to a person being called this? I'd like you to describe exactly what is meant by nakedness. 4

\section{Parāśara:}

The $R g$, Yajur and Säma Vedas are a threefold garment for the various communities, brahmin, but a deluded individual who casts off this mantle is regarded as both sinful and naked. 5

Because the three Vedas clad each community, when they're cast aside, an individual is surely rendered naked. $\sigma$

Listen to what our ancestor Vasistha, who understood tradition, said to mighty Bhīṣma. 7

This is what I heard that great-souled individual say with regard to nakedness, and which you asked about just now. 8

Long ago, the deities waged a war against the demigods, brahmin. During that confrontation, which continued for one divine year, they were routed by the Daityas led by Hrāda. 9

The deities then retreated to the Milky Ocean's northern shore, where they undertook austerities to propitiate Lord Viṣnu, and they sang this song of praise: 10 


\section{The gods praise Viṣnu}

\section{The deities:}

May Lord Viṣnu, first among beings and master of the worlds, be pleased with this song we sing to worship him. 11

Who can sing the praises of that great being, the origin of all creation, into whom it dissolves again? 12

Although our power was thwarted in this battle, desiring our own felicity, we still praise you, even though your actual nature is beyond the reach of words. 13

You are earth, water, fire, wind, space, mind, primal matter and the highest spirit beyond them all. 14

You are at the heart of all creation. This whole world, from Brahmā to a tuft of grass, both formed and formless, is your single body, only split by time and place. 15

We bow to you, Lord, in the form of Brahmā, who first arose from the lotus at your navel to create the world. 16

We bow to your divine form, divided among ourselves as mighty Indra, the Sun, Rudra, the Vasus, Aśvins, Maruts, the Moon and others. 17

We bow to you, Govinda, in the form of Daityas: deceitful, ignorant, impatient and unrestrained. 18

We bow to you in the form of yakșas, whose frivolous hearts lack discernment and who hanker for sensations such as sound. 19

We bow to you, highest spirit, in the form of night-ranging rākṣasas: cruel, deceptive, fierce and dark. 20

We bow to you, Janārdana, in the form called dharma, which yields rewards of truest virtue for pious beings who dwell in heaven. 21

We bow to you, success embodied, in the form of siddhas, those perfected beings consisting of unalloyed bliss, the goal of all departures. 22

We bow to you, Hari, in the form of nāgas: fork-tongued, resilient, cruel and bent on pleasure. 23

We bow to you, Viṣnu, in the form of sages: knowledgeable, tranquil, pure and faultless. 24 
We bow to you, lotus-eyed deity, in the form of Time, which, unstoppable, consumes all creatures when each aeon ends. 25

We bow to you in the form of Rudra, who, having swallowed all creation including gods, dances at the destruction of the world. 26

We bow to you, Janārdana, in the form of humankind, the motive force of acts that are carried out with energy. 27

We bow to you, the universal being, in the form of animal life, which ends in twenty-eight modes of death and, marked by stupidity, often goes astray. 28

We bow to you, the foremost one, the diverse being differentiated into trees and other kinds of plants, which provide the basis for the sacrifice, and which in turn allow perfection of the world. 29

We bow to you, universal being, whose initial form is the elements including space and sensations such as sound, all of which are experienced by animals, humans, deities and the rest. 30

We bow to you, the highest being, cause of every cause, whose ultimate form is distinct from us and all that consists of matter, intelligence and so on, and has no equal. 31

We bow, Lord, to that form that has no colour such as white, no dimension such as length and no quality such as density, which is beyond the range of descriptions, which is the purest of the pure and is perceptible only to the highest sages. 32

We bow to that form of the Absolute that is in our bodies, and in others, and in all things, unborn, unchanging and beyond which there is nothing. 33

We bow to the stainless Lord Vàsudeva, the highest state, the everlasting unborn being whose form is all the universe, who has no end and is the seed of all creation. 34

\section{Viṣnu creates a phantom}

\section{Parāśara:}

At the conclusion of this paean, the deities beheld the supreme Lord Hari, holding the conch, sword and discus, mounted on Garuda. 35

Falling to the ground, the host of deities, seeking his protection, beseeched him: 'Be merciful to us, Lord, and save us from these Daityas. 36 
Led by Hrāda, the demons have deprived us of all three worlds and our portion of the sacrifice, highest Lord, ignoring the injunctions of the Vedas. 37

Even though we deities and Daityas are merely aspects of you, the universal being, we still perceive the world to be divided, such differences appearing as the result of ignorance. 38

Adhering to the traditions of our own community, following the Vedic path and filled with ascetic energy, we still cannot destroy our enemies. 39

Give us, please, the means, universal Lord, by which we may defeat the demigods.' 40

\section{Parāśara:}

Thus addressed by the deities, Lord Viṣnu produced a phantom from his body, which he presented to the best of gods with this explanation: 41

The Lord:

When this phantom has confused the Daityas, you'll be able to kill them all, as they will have left the Vedic path. 42

I'm inherent in all creation, and any who offend the Vedas will be destroyed by me. All divine beings, including gods and Daityas and the rest, are subject to Vedic authority. 43

Go, therefore, and do not fear. Proceed with the phantom before you, gods-it will serve you well this very day. 44

\section{Parāśara:}

Hearing this, the deities bowed again to Viṣnu and returned as they had come, accompanied by the phantom, to confront the mighty demigods. 45

So ends Chapter Seventeen in Book Three of the glorious Viṣnn Purāna.

\section{The phantom confounds the demigods}

\section{Parāśara:}

When the phantom reached the banks of the Narmadā River, Maitreya, he saw the mighty demigods engaged in ascetic practice. 1 
Taking the form of a naked holy man, shaven-headed and carrying a peacock feather, brahmin, the phantom addressed the demigods with gentle words. ${ }^{11} 2$

\section{The phantom:}

Greetings, Daitya lords! Tell me, why do you practise these austerities? Do you desire a reward in this world or the next? 3

\section{The demigods:}

We undertake these practices because we want rewards hereafter. Why do you ask, wise sage? 4

\section{The phantom:}

You must follow my instructions if you wish for liberation. You must be worthy of my religion, as it's the door to freedom that never closes. 5

This noble religion of liberation is the best. Once established in this tradition, you'll proceed to heaven or to freedom from existence. 6

But you mighty beings must first prove worthy! 7

\section{Parāśara:}

With many such cunning words to inculcate his views, the phantom led those Daityas from the Vedic path. 8

He taught that vice is virtue, truth is falsehood and that which leads to liberation does not do so, 9

That which is absolute highest truth is not so; 10

That which is to be done is not so; that this is wrong and that is right; that this is the religion of naked ascetics, and that is the religion of those who dress. 11

Such were the endlessly repeated blandishments, brahmin, by which the phantom induced the Daityas to shun their own religion. 12

Since the apparition told them they were worthy (arbatha) of his great tradition, they trusted him, converted to Jainism and became Arhats. 13

After the phantom caused the demigods to abandon the traditions of the threefold Vedas, they began to instruct others. 14

11 This is a thinly veiled reference to the naked Jain ascetics of the Digambara tradition. The feather was used to brush living things safely out of their path. 
These others taught others again, and they in turn taught even more, so that within a few days every Daitya left the Vedic path. 15

Some time later, wearing monkish saffron robes, the phantom, whose gaze was irresistible, approached another group of Daityas and spoke to them with simple words, both soft and sweet: ${ }^{12} 16$

\section{The phantom:}

If you want to go to heaven or reach nirvāna, you demigods must give up this false religion, including the animal sacrifice. Listen! 17

Understand that this whole world consists of knowledge. Understand my words in full, as they were uttered by the wise. 18

All the world has no foundation, but is ever bent on chasing baseless knowledge. Plagued by passion and other such emotions, it's caused to wander through the straits of being. 19

\section{Parāśara:}

When the phantom said, 'Understand! Understand!', the Daityas said, 'We understand', and thus he led them from their own traditions. 20

Precisely in accord with these varied false instructions, which the phantom thrust upon them, the Daityas then abandoned true religion. 21

They also taught this doctrine to others, and those others taught others again, Maitreya, and they all forsook the true religion prescribed by the Vedas and sacred law. 22

The phantom, that great purveyor of delusion, brahmin, also confounded other Daityas with many varied heresies. 23

In little time, the demigods, led astray by him, no longer spoke of the threefold Vedic path. 24

Some disparaged the Vedas, others insulted the deities, brahmin, and some belittled the totality of sacrifice, ritual action and even the brahmin order: 25

'Violence towards animals for a sacrifice has no part in true religion. Such a necessity is mistaken. To say that butter burnt in fire can yield rewards is childish nonsense. 26

12 The following verses refer to Buddhism. In verses 18 and 20, the words budhaih, budbyata, budbyadbvam and budbyate ('understand', and so on) are all cognate with the word 'Buddha'. 
If Indra, having reached the status of a god through many sacrifices, is fed with wood from sami-trees or similar, then he's no better than wild beasts which eat the leaves. 27

If the beast that's sacrificed then goes to heaven, why doesn't the sacrificer kill his father? 28

If food that's eaten by someone at a śräddha nourishes another, then those who live afar could offer it wherever they are and need not faithfully bring it to the ceremony. 29

Once you understand what people may reasonably believe, then you'll see the benefits expected from the words I've spoken. 30

Wise words don't simply fall from heaven, mighty demigods, and reasonable instruction should be acceptable to me and others of your kind.' 31

\section{Parāśara explains 'nakedness'}

\section{Parāsara:}

The phantom misled the Daityas with so many notions that not one continued to accept the authority of the threefold Vedas. 32

When the Daityas strayed along these paths of falsehood in this manner, the deities prepared for war and advanced upon their foe. 33

The battle of the gods and demigods resumed, brahmin, but on this occasion, the demons were overcome by those who took the path of truth. 34 As the Daityas had forsaken the armour of true religion that protected them before, brahmin, they were overcome. 35

That's why, Maitreya, those who took the path of truth, but vainly shed the safety of the threefold Vedas, are called 'naked'. 36

Student, householder and forest-dweller, with wandering mendicant as the fourth - these are the stages of life. There is no fifth. 37

The wicked man who abandons married life but doesn't retire to the forest or become a mendicant, Maitreya, is also naked. 38

One who fails to perform an obligatory ritual, brahmin, even though he's able, spoils his obligatory rites for an entire day and night, and on that very day, is fallen. 39

One who neglects his regular rites, except in an emergency, Maitreya, only regains his state of purity after a fortnight of sincere atonement. 40 
Seeing a man who has neglected his rituals for a year, virtuous people must turn their gaze upon the sun. 41

If they touch that man, they purify themselves by bathing fully clothed, great sage, but no expatiation is prescribed for the evildoer himself. 42

There is no baser person in the world than one in whose house the deities, sages, ancestors and spirits, being neglected, heave a sigh and go away. 43

One should avoid the house, the seat or property of a person whose body or residence has felt the sighs of gods and other beings. 44

One who converses with, inquires after or socialises with such a person, brahmin, incurs the same portion of guilt, which endures for one whole year. 45

If one eats with such a person, sits in his house or lies on a couch with him, he immediately becomes the equal of the sinner. 46

One who eats without honouring the deities, ancestors, spirits or guests is guilty of a misdeed. How great is his negligence! 47

Brahmins and members of other orders who turn their backs on their own traditions are also described as 'naked' and are ranked with those who neglect their rites. 48

Living in a place where there's excessive contact among the orders is harmful to those of virtuous conduct. 49

Those who speak with a person who eats before honouring sages, deities, ancestors, spirits and guests will go to hell. 50

A wise man should therefore always avoid conversation or any other contact with these 'naked' individuals, who are defiled by rejection of the threefold Vedas. 51

A śräddha diligently performed by pious individuals brings no satisfaction to gods or spirits if 'naked' people see it. 52

\section{King Śatadhanu is born as a dog}

Long ago, it's said, a king called Śatadhanu had a pious wife named Śaibyā. 53 Faithful, fortunate, truthful, pure and kind, Śaibyā was blessed with decorum and every other virtue. 54 
The royal couple worshipped Lord Janārdana, god of gods, with deep devotion. 55

Day after day, they devoutly undertook oblations, prayers, donations, fasts and rituals with their hearts on him alone. 56

One day, the royal couple, who were fasting on the full-moon day of the month of Kārttika, emerged from the waters of the Bhāgīrathī River in which they'd bathed together, brahmin, and saw a heretic drawing near. 57

Because the heretic was a friend of the monarch's archery instructor, the king, out of respect for his teacher, engaged the man in conversation. 58

But his wife, the queen, observant of her vow, said nothing and, because she was fasting, raised her eyes to the sun when she saw the stranger. 59

On returning to the palace, the king and queen duly completed their worship of Viṣnu and other deities as prescribed, best of brahmins. 60

In time, the once victorious king expired, and the queen ascended his pyre to join her husband where he lay. 61

Because of his transgression of speaking to a heretic in a time of fasting, the king was born as a dog. 62

The queen, however, was born as the brilliant daughter of the king of Kāsi and could recall her previous lives. She possessed all forms of knowledge and wore each desirable quality as an ornament. 63

Her royal father sought a husband for her, but that slender girl dissuaded him and so she never married. 64

Sometime later, the princess, who possessed divine insight, beheld the dog, her former husband. She journeyed to the city known as Vaidiśa, where she found him. 65

The fortunate girl, recognising her husband in that form, gave him nice things to eat and treated him with kindness. 66

Eating the tasty and desirable food she gave him, and playing about as dogs are wont to do, he repeatedly showed her his affection. 67

The young girl, however, was embarrassed by his friendliness and, bowing deeply, addressed her beloved husband, who had suffered such a lowly birth. 68 


\section{The wife:}

Try to remember the kindly greeting you gave the heretic, your majesty, on account of which you were born as this dog, now showing me such friendship. 69

You addressed that man after we bathed together at the sacred ford, and now you've had this deplorable rebirth. Do you not remember, lord? 70

\section{Parāśara:}

Reminded of his former life, he reflected for a while and was filled with dreadful pain. 71

Broken-hearted, the dog set out from the city and died in the desert, where he was born as a jackal. 72

The following year, the princess, using her divine insight, perceived all this and journeyed to Mount Kolāhala to see him. 73

Beholding him there, the delicate princess addressed her husband born from a jackal's womb. 74

The wife:

Don't you remember, your majesty, what I told you when you were born as a dog, about the time you addressed that heretic? 75

\section{Parāśara:}

Realising she had spoken truly, and being the best of those who understand such words, the jackal in the wilderness then starved himself to death. 76

Once more, the blameless princess found him, reborn this time as a wolf in a lonely forest, and reminded him of his prior fault: 77

'You're not a wolf, you fortunate being, but King Śatadhanu. You were born as a dog, a jackal and now this creature.' 78

\section{Parāśara:}

Reminded of his true identity, the king was born as a vulture. Once more, the sinless beauty informed him of his past: 79

'Your majesty, remember what you used to be. Give up this vulture's life! You're in this state because you erred in talking to a heretic.' 80

As a result, he was born as a crow in his next life. Using her special powers, that slender girl located him and said: 81 
'All the sovereigns on the earth paid tribute to you formerly, but now you're born as a crow that scavenges food oblations, lord. ${ }^{13} 82$

\section{Parāśara:}

The king in corvine form was thus reminded of his past, and, having drawn his final breath, was born as a peacock. 83

The splendid girl pursued that bird and always fed it things that peacocks like to eat. 84

A little later, her royal father performed a great horse-sacrifice, at the end of which the peacock received a ritual bath. 85

The girl with slender limbs then bathed herself and reminded the former king how he'd been born as a dog, a jackal and the others. 86

Remembering this string of births, he left his body and was born as the son of a man of exemplary standing. 87

When the slim girl pressed her father on the matter of her wedding, he arranged a svayamvara for her. ${ }^{14} 88$

On the day of that event, her former husband was the man the splendid princess chose. 89

The prince partook of many pleasures together with his wife, and, when her royal father died, the realm of Videha passed to him. 90

He performed many great sacrifices, made donations to the poor, fathered many sons and vanquished all his enemies. 91

Having duly ruled his realm and defended all the earth, the king, following tradition, died in battle. 92

Once more that fair-eyed woman, filled with joy, duly climbed her husband's pyre as she had done so long ago. 93

Together with the princess, the king now passed beyond the heavenly realms of Indra to reach eternal regions where all wishes are fulfilled: 94

13 This verse contains a pun on the word bali, which means both the tribute paid by kings and the food offerings made to the ancestral spirits, which are later eaten by the birds.

14 An assembly of suitors from which a princess may choose a husband-along the lines of 'The Bachelorette', as one of my students suggested. 
That unequalled, unending paradise, which is the rarely won reward for merit earned in marriage, best of brahmins. There he reached a state of perfect purity. 95

Such is the sin of speaking with a heretic that I've described, brahmin, and the efficacy of a ritual bath at the conclusion of a horse-sacrifice. 96

That's why one should never speak with wicked apostates or contact them, especially during rituals or when initiated for a sacrifice. 97

If a prudent person is required to look up to the sun when he's seen a man whose rituals have been neglected for a month, 98

How much greater the expatiation when one has contact with a sinner who whole-heartedly forsakes the threefold Vedas, eats food prepared by members of the lower orders or opposes Vedic teachings? 99

One should never honour heretics, those who act unlawfully, false saints like the cat in the famous story, charlatans, sceptics or hypocrites like the fabled heron, or even speak with them..$^{15} 100$

One should keep one's distance from the wicked, heretics and those of doubtful conduct, and avoid their company. It's therefore best to stay away from them. 101

I've described to you the people known as 'naked', the sight of whom will spoil a śäddha. By speaking to such apostates, a full day's merit will be lost. 102

As these heretics are evil, a wise man shouldn't speak with them, but if he does, all the merit earned that day is lost. 103

Men will go to hell for speaking with those who wear their hair in matted locks, or shave their heads, or vainly eat before others do, or disregard the rules of purity, or are forbidden to offer food or water to the ancestors. 104

So ends Chapter Eighteen in Book Three of the glorious Viṣnu Purāna.

End of Book Three.

15 The cat and heron are well-known hypocritical characters in fable collections such as the Pañcatantra and Hitopadeśa. 
This text is taken from The Viṣnu Puranna: Ancient Annals of the God with Lotus Eyes, translated from the Sanskrit by McComas Taylor, published 2021 by ANU Press, The Australian National University, Canberra, Australia.

doi.org/10.22459/VP.2021.03 